\title{
The external financing of investment
}

\author{
Bruce D. Grundy ${ }^{\text {a }}$, Patrick Verwijmeren ${ }^{a, b, *}$ \\ ${ }^{\text {a }}$ University of Melbourne, Australia \\ ${ }^{\mathrm{b}}$ Erasmus School of Economics, Erasmus University, Rotterdam, the Netherlands
}

\section{A R T I C L E I N F O}

\section{JEL classification:}

E22

G32

\section{Keywords:}

Investment characteristics

Financing

Debt-equity choice

Convertible securities

\begin{abstract}
A B S T R A C T
This paper investigates the impact of investment characteristics on the financing choice. We investigate instances of seasoned equity, bank debt, straight non-bank debt, and convertible issues by U.S. firms where the stated use of proceeds is capital expenditure and where we are able to hand-collect and classify the characteristics of the investment. Controlling for a firm's existing assets, capital structure and valuation, we document a strong empirical link between an investment's characteristics and the choice between debt and equity financing. Factor analysis indicates that the principal determinant of the financing choice is whether an investment's payoffs can be described as a hit or miss.
\end{abstract}

\section{Introduction}

This paper examines the link between investment characteristics and the form of external financing by investigating all instances of seasoned equity, bank debt, straight non-bank debt, and convertible issues by U.S. firms between 1995 and 2017 where the stated use of proceeds is capital expenditure. Using hand-collected data, we examine seven characteristics: whether the investment is both tangible and non-unique; whether the investment is part of an R\&D program; the investment's expected life; the uncertainty surrounding that life; the time until the investment begins to generate positive payoffs; the volatility of the investment's payoffs; and the need for monitoring. ${ }^{1}$ A strength of our study is that we are able to examine the effect of each characteristic while controlling for the

\footnotetext{
We would like to thank Eric van den Heuvel, Corstian ten Hoor, Mats van Marle and Hugo Wolters for excellent research assistance. We thank Douglas Cumming, two anonymous referees, Gil Aharoni, Ali Akyol, James Brugler, Tze Chuan Ang, Sjoerd van Bekkum, Tobias Berg, Les Coleman, Claudia Custodio, Eric Duca, Marie Dutordoir, Pengda Fan, Neal Galpin, Ning Gong, Jens Hagendorff, Georges Hübner, Joachim Inkmann, Patrick Kelly, Matti Keloharju, Sotirios Kokas, Marie Lambert, Mikko Leppamaki, Ed Lin, Anders Loflund, Stefano Maiani, Immacolata Marino, Lyndon Moore, Wei Opie, Sebastian Pfeil, Zacharias Sautner, Harminder Singh, Manmohan Singh, Günter Strobl, Sheridan Titman, David Yermack, Jing Zeng and seminar participants at Deakin University, the Frankfurt School of Finance and Management, University of Melbourne, University of Western Australia, University of Liège, University of Glasgow, University of Essex, Aalto University, Hanken School of Economics, the 2017 MBF conference, 2017 Paris Financial Management Conference, 2017 Australasian Banking and Finance conference, and the Queen's Workshop on Corporate Finance for helpful comments. Part of this work was completed while Grundy was visiting the McCombs School of Business and the Erasmus School of Economics.

* Corresponding author at: Burg. Oudlaan 50, 3000 DR, Rotterdam, the Netherlands.

E-mail addresses: bruceg@unimelb.edu.au (B.D. Grundy), verwijmeren@ese.eur.nl (P. Verwijmeren).

1 Other studies that focus on the financing of new investments do not examine their characteristics. Dudley (2012) examines Compustat firm-years in which investments exceed 1.5 times the median industry rate, while Elsas et al. (2014) examines Compustat firm-years in which investments exceed $30 \%$ of assets. These papers link the debt-equity choice to the difference between firms' existing and target capital structures, a measure that we incorporate as a control.
} 
other characteristics. We document that five of these seven characteristics are statistically significant determinants of the financing choice. Investments with more distant and more volatile payoffs are more likely to be financed with equity rather than debt. In contrast, investments in tangible, non-unique assets or in assets that require a high level of monitoring are more likely to be financed with debt rather than equity. Investments in $R \& D$-like programs are more likely to be financed with equity than with non-bank debt but are equally likely to be financed with bank debt as they are to be financed with equity.

Our interest is in the debt-equity choice of firms that finance their investments externally. As any sample of externally-financed investments conditions on the fact that the firm was either unwilling or unable to finance via retained earnings, the results in a study on security issuance are conditional on firms raising external finance (MacKie-Mason, 1990). A limitation of a study of investment characteristics and financing is that the study can only be undertaken for those investments that are reported in sufficient detail to allow the characteristics to be determined. Our analysis includes a Heckman correction because of the possibility that the detailed information necessary to determine investment characteristics is more likely to be available in issuer announcements and press stories when an investment is equity-financed.

Our results contribute to the large literature on capital structure, much of which examines the determinants of firm capital structure. Our aim is to obtain the insights provided by a direct focusing on the external financing of investments. Our study on individual investments and financing choices adds to the insights from studies using firm-level data on capital structure and asset structure because firm-level capital structure can deviate from its optimum, for example because of past profitability. ${ }^{2}$ An examination of the financing of new investments focuses on the situation when the relevant transaction cost of issuing securities is only the difference in the costs of issuing debt versus equity. In such a setting, managers can place a greater focus on future restructuring costs, agency costs, taxes, information asymmetries, and security mispricing issues inherent in an investment's characteristics.

Our study identifies the time until an investment produces positive payoffs as an important determinant of the financing choice. This characteristic has received little attention in prior research. A firm that borrows to finance investments whose payoffs do not begin for some time must cover the interim interest payments through additional borrowing, which will involve additional transactions costs and initially holding some low-return liquid assets. Further, the corporate-tax saving associated with interest deductions cannot be enjoyed until the investment produces taxable income (Barnea et al., 1987; Berens and Cuny, 1995). Our investigation is the first to directly demonstrate that more distant cash flows are strongly associated with an increased likelihood of equity financing.

Our results link to prior studies on asset redeployability. Titman (1984), Titman and Wessels (1988), Shleifer and Vishny (1992) and Benmelech (2009) observe that it is the combination of tangibility and the non-uniqueness that determines whether an asset has collateral value. Our examination of the investment characteristics highlights the importance of asset redeployability (an alternate term for non-uniqueness) as a determinant of leverage by showing that investments that are both tangible and non-unique are significantly more likely to be debt-financed than tangible investments that are unique; i.e., that tangibility alone can be a poor proxy for collateral value. Our result corroborates the firm-level analyses of capital structure and redeployability in Campello and Giambona (2013) and Nyatee (2017).

We also examine the link between investment characteristics and the decision to finance via a convertible debt issue. Convertible bond issues are increasingly used as a means of financing and a substantial literature attempts to establish rationales for the issuance of convertible bonds (Lewis et al., 1998; Dutordoir et al., 2014). Our results on convertible financing and investment characteristics are in line with the rationale of Mayers (1998) that convertibles are useful for sequential financing purposes. We find that investments with highly volatile payoffs and a highly uncertain life increase the likelihood of financing via a convertible security since both characteristics increase the benefit from being able to force conversion during a staged-investment program.

An important contribution of our paper lies in its use of factor analysis to identify the principal dimensions along which investments differ. The high correlations between investment characteristics highlight the importance of a simultaneous examination of the set of characteristics. Factor analysis identifies a small set of factors that capture the explanatory power of the seven characteristics. The first and most important factor loads positively on R\&D, the time until positive payoffs, investment life uncertainty, payoff volatility, and the need for monitoring, and negatively on the tangible, non-unique investment characteristic. The interpretation of this factor is that investments vary primarily in terms of how well success versus failure describes the future payoffs. We term investments with successversus-failure style payoffs as hit-or-miss investments. A regression of the debt-equity choice on this first factor indicates that hit-ormiss investments are more likely to be financed via equity. The pseudo $R^{2}$ of a logit regression that includes all seven characteristics is $48 \%$. When the seven individual characteristics are replaced by the single first factor, the model explains $43 \%$ of the variation in the debt-equity choice. We conclude that the hit-or-miss nature of an investment represents the main dimension along which investments vary and that this dimension has a primary role in explaining the debt-equity choice.

The paper is organized as follows. Section 2 discusses the theoretical link between investment characteristics and the debt-equity choice and the predicted sign of the coefficients of a logistic regression of financing choice on investment characteristics and controls suggested by the literature. Section 3 describes the classification of investment characteristics. Section 4 reports our primary results. The importance of the interaction of tangibility and non-uniqueness for measuring collateral value is emphasized and the time until positive payoffs is shown to be an important but previously underexplored determinant of the financing choice. Section 5 shows that our results are little changed when a Heckman two-stage sample selection procedure is employed. Section 6 investigates the set of common factors underlying investment characteristics and the link between these factors and the debt-equity choice. Section 7 examines the link between convertible bond financing and investment characteristics and Section 8 contains our conclusions.

\footnotetext{
${ }^{2}$ Strebulaev (2007) notes that the observed cross-sectional relation between asset characteristics and leverage will then be a noisy variant of the optimal relation.
} 


\section{Investment and the financing choice}

\subsection{Investment characteristics and the financing choice}

We investigate the link between financing and seven investment characteristics: whether the investment has high collateral value, with I(Tangible \& Non-unique) being a zero-one indicator; whether the investment is part of a sequential program, with $I(R \& D)$ being a zero-one indicator; the expectation of the investment's life, Investment Life, in number of years; the time until the investment begins to produce positive payoffs, with I(Time until Payoffs) being a tri-valued indicator of whether the asset will first produce positive payoffs within one year of the investment, after one year but within five years, or after more than five years; the level of uncertainty surrounding the investment's life, with I(Investment Life Uncertainty) being a zero-one indicator of whether that uncertainty is classified as low or high; whether the volatility of the investment's payoffs is high, with I(Volatility) being a zero-one indicator of whether volatility is classified as low or high; and whether a high degree of monitoring is required, with I (Need for Monitoring) being a tri-valued indicator of a low, medium, or high potential for suboptimal operation of the investment.

Trade-off theory predicts a positive link between collateral value and debt financing. This prediction is subtler than it appears. Grundy (1977) and Haugen and Senbet (1978) observe that if, for example, liquidation costs would also have been incurred by allequity firms experiencing poor performance, then the incurrence of this component of bankruptcy costs is not due to leverage per se. The event of bankruptcy and the decision to bear the costs of liquidation may be correlated in time, but the marginal liquidation costs associated with debt-financing would be zero and the collateral value of an investment need not affect its financing. However, stockholder-bondholder coordination costs result in levered and unlevered firms making different restructuring decisions (Titman, 1984). White (1989) shows that coordination costs in conjunction with the U.S. bankruptcy code can lead levered firms to continue loss-making operations when an otherwise equivalent all-equity financed firm would liquidate or otherwise restructure. ${ }^{3}$ When assets have high collateral value, more secured debt can be issued without risking bankruptcy and the need for coordination.

There are also information asymmetry-based reasons why assets with high collateral value are more likely to be financed with debt. White (1989) observes that secured loans have the advantage that secured lenders need only monitor the assets subject to the lien and not the firm's overall financial condition. Myers and Majluf (1984) establish that information asymmetries can make it optimal to finance high collateral value investments with debt. A high collateral value means a high lower bound on the investment's future value and in turn a high minimum payoff for debt claims on the investment. ${ }^{4}$ In summary, both trade-off theory and information asymmetries predict that investments with high collateral value are less likely to be equity-financed.

Determining whether an asset has high collateral value is not straightforward. Campello and Giambona (2013) emphasize that tangibility alone can be a poor proxy for collateral value. Titman (1984) and Titman and Wessels (1988) introduce the notion that an asset must be non-unique for it to be marketable. Accordingly, tangibility and non-uniqueness are joint determinants of collateral value (Shleifer and Vishny, 1992; Benmelech, 2009; Kim and Kung, 2017; Nyatee, 2017). For example, the empirical analysis of firm leverage in Nyatee (2017) captures an investment's redeployability (an alternate term for non-uniqueness) by using an industry-level measure of the number of potential buyers of firms' assets. We use an investment-specific measure of redeployability, based on both tangibility and non-uniqueness. We predict that investments where the I(Tangible \& Non-unique) indicator is equal to one are more likely to be debt-financed.

Both trade-off theory and agency theory predict that sequential investments like R\&D programs are more likely to be equityfinanced. ${ }^{5}$ Given its intangibility, R\&D has little collateral value and hence the likelihood of a suboptimal restructuring decision will be higher if R\&D projects are debt-financed. Further, Myers (1977) and Barclay et al. (2006) observe that debt overhang problems can mean forgoing the valuable growth opportunities inherent in sequential investment programs. Li and Mauer (2016) examine the interaction between investment and financing decisions in dynamic settings and predict that firms will finance the acquisition and exercise of growth options with equity in order to preclude a future debt overhang. ${ }^{6}$ Mayers (1998) argues that if a sequential investment program is financed with a callable convertible rather than with straight debt, then when the firm wants to proceed to the next stage, a call can force conversion and eliminate any debt overhang. Thus Mayers (1998) and Li and Mauer (2016) predict that investments where the $I(R \& D)$ indicator is equal to one are more likely to be financed with equity or convertible debt than with straight debt.

The theoretical link between Investment Life and optimal financing is not clear. All else equal, if long-lived assets have high collateral value, then long-lived assets will be more likely to be debt-financed. The "all else equal" condition is important. Rampini (2019) argues that the argument that durable assets can serve as collateral and thereby facilitate debt financing may be flawed since durability affects the purchase price of an asset (and hence the overall financing need) by more than it affects the asset's collateral value. As argued in Baker (2009), capital supplier preferences can underlie a quite separate link between debt issuance and asset life. For example, insurance firms have a specific demand for long-term debt. If maturity matching means that investments with long-term cash flows make it easier to issue long-term debt, then insurers' preferences will be satisfied when long-term debt is issued against longlived assets. This link between investment characteristics and financing relates to debt maturity rather than the debt-equity choice. The

\footnotetext{
${ }^{3}$ See Acharya et al. (2011) for more insights into the relation between bankruptcy codes and firms' capital structure choices.

${ }^{4}$ Hart and Moore (1994) also consider the effect of collateral value on financing but do so in a model of inalienable human capital in which entrepreneurs choose between abandoning or undertaking projects and investments are financed via public debt and the entrepreneurs' own funds.

${ }^{5}$ See Cortazar et al. (2001) and Hsu and Schwartz (2008) for analyses of the sequential investments inherent in R\&D.

${ }^{6}$ Frantz and Instefjord (2019) study the restructuring of debt in the presence of debt overhang for firms with investment opportunities.
} 
extant literature does not provide a clear prediction as to the relation between Investment Life and the debt-equity choice.

We expect a positive relation between the choice of equity financing and an investment's Time until Payoffs. If the payoffs from an investment only arrive after a considerable delay, then when the investment is financed with debt, the firm will have to borrow more to cover the initial interest due on the debt. Cumming (2005) shows that seed stage entrepreneurial firms are more likely to be financed by equity, in line with seed firms lacking income streams that can service interest payments on debt. Further, unless the firm has income from its other investments, the corporate tax saving associated with interest deductions cannot be enjoyed until the specific investment produces taxable income (Barnea et al., 1987; Berens and Cuny, 1995). One reason for a delay before an investment produces cash flows is simply the time taken to physically complete construction. Tsyplakov (2008) analyzes a dynamic model that contains a time-to-build lag and predicts a greater reliance on external equity financing the longer is the delay until an investment's future payoffs can be sheltered from tax by deductible interest payments. ${ }^{7}$ We investigate the effect of the Time until Payoffs controlling for the other determinants of the debt-equity choice and predict that the longer the Time until Payoffs, the more likely the investment will be equity-financed.

When an investment is debt-financed, maturity matching reduces both refinancing costs and agency-related debt overhang problems (Myers, 1977; Barclay and Smith, 1995; Stohs and Mauer, 1996). Matching is more difficult when the investment's life is uncertain. Hence, we predict that investments where the investment life uncertainty is high (i.e., the indicator I(Investment Life Uncertainty) is one) are more likely to be financed with equity. Payoff uncertainty can also affect the financing choice. If an investment with highly volatile payoffs is financed with debt, there will be a high chance of a future stockholder-bondholder coordination problem and a suboptimal restructuring. Trade-off theory then predicts that investments where the payoff uncertainty is high (i.e., the $I$ (Volatility) indicator is one) are more likely to be equity-financed.

The need to monitor an investment will also affect its financing. Debtholder monitoring occurs when financing via a series of shortterm debt issues forces the periodic reevaluation of a project. Debtholder monitoring also occurs when an investment with collateral value is financed with secured debt, which effectively links the maturity and priority of the loan to how well-informed the lender chooses to be (Rajan and Winton, 1995). The ability to acquire monitoring by placing equity with a blockholder (Burkart et al., 1997; Edmans, 2014) will not be a major determinant of the debt-equity choice for the sample of investments whose financing and characteristics we can determine and analyze as the far majority of equity issues in our sample are public issues. Thus, we predict that for investments financed by either debt or public equity, the larger the I(Need for Monitoring) indicator, the more likely it is that debt financing will be observed.

\subsection{Firm level determinants of the financing choice}

A firm's existing assets and its existing and optimal capital structures will also influence how any new investment is financed. For example, a firm that has performed well since its capital structure was last re-optimized may have become under-levered and whatever the characteristics of a new investment, the firm may have an incentive to finance with debt. We therefore include as a control for the incentives created by the firm's existing assets and capital structure, the target deviation variable examined in Hovakimian et al. (2001). Hovakimian et al. (2001) (Firm HOT) find that equity is more likely to be issued when the absolute deviation from target leverage if the firm were to issue debt relative to the absolute deviation if the firm were to issue equity is larger. ${ }^{8}$

Estimating the Firm HOT measure requires a proxy for the firm's target leverage ratio. As one proxy we use the predicted value obtained from a regression of book leverage on lagged firm size, profitability, tangibility, market-to-book ratio, depreciation, R\&D expenses, a dummy equal to one if the firm reported R\&D expenses, industry median book leverage, and expected inflation estimated for all industrial Compustat firms. ${ }^{9}$ As an alternative proxy we use the median leverage of the firm's industry-year with industries defined by the Fama-French 12 industry classification. Our qualitative results and the conclusions drawn do not depend on which of the two proxies for target leverage is used.

The extant literature suggests several additional determinants of target leverage. Firms that have, say, shunned debt in the past relative to what might be predicted from our regression estimate of the firm's target are likely to continue to do so (Lemmon et al., 2008). Strebulaev and Yang (2013) present evidence consistent with the observed persistence in firm leverage ratios reflecting CEO preferences. Since our data set does not contain sufficient instances of different investments by the same firm for us to include firm fixed effects (most firms appear only once in our sample), we also include book leverage at the end of the financial year preceding the issue, Firm Book Leverage, as a control.

Pecking order theory argues that firms will issue equity when financial distress costs loom large or a debt issue would constrain the firm's future actions too tightly. Thus, we also include the size of the investment relative to the market value of the firm's equity, Firm Proceeds/MV Equity, as a control. The larger the relative size of the investment, the more likely it will be equity-financed (de Jong et al., 2010). Another reason why some firms may prefer to issue equity is that regardless of the characteristics of a specific new investment, firms with high growth opportunities will be less willing to risk a future debt overhang. We therefore include firm-level R\&D expenditures relative to sales, Firm $R \& D /$ Sales, as a control for growth opportunities.

Market-timing implies that the financing of a new investment can provide a convenient opportunity to issue shares if management

\footnotetext{
7 Tsyplakov (2008) shows that a proxy for time-to-build based on depreciation charges is negatively related to firm size and concludes that the negative relation between firm size and equity financing demonstrates that financing reflects an investment's time-to-build lag.

${ }^{8}$ Including the Firm HOT measure as a control makes no assumption about the speed of adjustment to the target.

9 This set of predictors reflects the analysis of firm-level capital structure in Flannery and Rangan (2006) and Frank and Goyal (2009).
} 
perceives the firm's equity as overvalued (Baker and Wurgler, 2002; Warusawitharana and Whited, 2016). As proxies for a perception of equity misvaluation, we include the equity's market value relative to its book value, Firm $M B$, and relative to its past value measured by the cumulative stock return over the year prior to the new issue, Firm Stock Performance. A second reason why a high Firm MB ratio may be associated with the choice of equity to finance additional investment is that the ratio can be a proxy for growth opportunities (see, e.g., Adam and Goyal, 2008).

\subsection{Logistic regression}

We use a logistic regression of the relative likelihood that an investment is financed by equity rather than debt to investigate the relation between investment characteristics and the financing choice conditioning on the set of controls discussed in Section 2.2. We examine the set of all externally-financed investments by U.S. firms between 1995 and 2017 for which information on the investments' characteristics can be sourced. As explained in Section 3 and 4, after conditioning, we have observations on 680 investments financed with debt or equity to estimate the thirteen $\beta$ parameters of the logistic regression in (1) below. Given the limited size of this comprehensive sample, when we consider even more controls, they are added singly and designated as Control $k$.

$$
\begin{gathered}
\text { log odds }=\beta_{0}+\beta_{1} I(\text { Tangible } \& \text { Nonunique })+\beta_{2} I(R \& D)+\beta_{3} \times(\text { Log Investment Life }) \\
\left.+\beta_{4} I(\text { Timeuntil Payoffs })+\beta_{5} I(\text { Investment } \text { Life Uncertainty })+\beta_{6} I \text { (Volatility }\right) \\
+\beta_{7} I(\text { Needfor Monitoring })+\beta_{8} \times(\text { Firm HOT })+\beta_{9} \times(\text { Firm Book Leverage }) \\
+\beta_{10} \times(\text { Firm MB })+\beta_{11} \times(\text { Firm Stock Performance })+\beta_{12} \times(\text { Firm R\&D } / \text { Sales }) \\
+\beta_{13} \times(\text { Firm Proceeds } / \text { MV Equity })+\beta_{k} \times(\text { Control } k)+\varepsilon .
\end{gathered}
$$

The discussion of investment characteristics in Section 2.1 leads to the predictions that $\beta_{1}$ and $\beta_{7}$ are negative; $\beta_{2}, \beta_{4}, \beta_{5}$ and $\beta_{6}$ are positive; and no prediction is made concerning the sign of $\beta_{3}$. Turning to the control variables, the predicted signs of their coefficients are as follows: Trade-off theory predicts that $\beta_{8}$ is positive and $\beta_{9}$ is negative; Market timing theory predicts positive signs for $\beta_{10}$ and $\beta_{11}$; A desire by firms with valuable growth options to avoid debt overhang also leads to a positive prediction for $\beta_{10}$ as well as to the prediction that $\beta_{12}$ is positive. Pecking order theory predicts a positive value for $\beta_{13}$.

We consider several additional variants of Control $k$ in regression (1). First, to allow for the possibility that a firm's optimal financing choice will differ over its life cycle, we use $\log ($ firm age) as a variant of Control $k$. Second, because the cost of financial distress could cause more volatile firms to prefer equity we include stock return volatility as calculated over the period [-240, -40] as an alternate variant of Control $k$. Third, we consider net-operating loss carryforwards (NOLs) since firms with NOLs will not be able to enjoy an immediate benefit of the tax deductibility of interest. Trade-off theory then predicts a reduced incentive to issue debt (Graham, 1996). We use a dummy equal to one for firms with NOLs as a third variant of Control $k$. Finally, financing constraints can influence the debt-equity choice of firms able to finance externally. Hellman and Stiglitz (2000) model a setting where firms have private information about both the expected return and risk of new investment and show that either or both credit and equity rationing can occur. We consider the firm's $\log$ (assets), credit rating, Altman's z-score, SG\&A expense/total assets, and cash holdings relative to total assets as alternate proxies for financing constraints, and hence as alternate variants of Control $k$.

Financial constraints can also have another effect on the relation between the debt-equity choice and investment characteristics. Pecking order theory predicts that when information asymmetries are important, a firm will only finance an investment by issuing new securities if the firm is cash-constrained. When information asymmetries are important and a firm is cash-constrained, pecking order theory predicts that the firm will issue debt rather than equity provided the firm has sufficient "debt capacity". Investment characteristics that increase (decrease) debt capacity will therefore increase (decrease) the likelihood of debt financing by cash-constrained firms for which information asymmetries are important. An investment with a high value of I(Tangible and Non-unique) or high Investment Life might increase a firm's debt capacity and allow the issuance of more of the less information-sensitive form of financing, namely debt. Investment with high values of $I(R \& D)$, I(Time until Payoffs), I(Investment Life Uncertainty) and I(Volatility) might reduce a firm's debt capacity and force an information-sensitive, cash-constrained firm to increasingly turn to equity financing. As a proxy for whether a firm is cash-constrained, we use an indicator I(Insufficient Internal Funds) equal to one when the capital raised for investment exceeds the firm's cash and cash equivalents. We estimate a variant of (1) where the I(Insufficient Internal Funds) indicator serves as a further variant of Control $k$. We also add interaction terms between the investment characteristics and the I(Insufficient Internal Funds) indicator. If a subset of the cash-constrained firms face important information asymmetries, then we expect negative coefficients on the interaction between the I(Insufficient Internal Funds) indicator and I(Tangible and Non-unique) and on the interaction between the $I$ (Insufficient Internal Funds) indicator and Log Investment Life. Consider the first of these two interactions. Redeployable investments not only have high collateral value and suggest a higher likelihood of debt financing for firms that are not cash-constrained, the increase in debt capacity engendered by an investment in a high collateral value asset allows cash-constrained firms facing information asymmetries to finance with the less information-sensitive instrument, namely debt. Analogous reasoning predicts a negative coefficient on the interaction between the I(Insufficient Internal Funds) indicator and Log Investment Life and positive coefficients on the interactions between the I(Insufficient Internal Funds) indicator and each of $I(R \& D)$, I(Time until Payoffs), I(Investment Life Uncertainty) and I (Volatility). 


\section{Data}

\subsection{Externally-financed capital expenditure}

We construct our data set of externally-financed investments from two sources. Thomson One Banker SDC contains security issuance data for seasoned equity issues, convertible debt issues, and straight debt by U.S. firms between 1995 and 2017 and we extract those issuances for which the reported use of proceeds is capital expenditure. ${ }^{10}$ Only $5 \%$ of all issues report capital expenditures as a use of proceeds. Acquisitions of other companies are not classified as capital expenditures. The most common use of proceeds in issuer's registration statements is "general corporate purposes", which may be the result of the issuer not being willing to reveal proprietary information to competitors or preferring spending flexibility (Walker and Yost, 2008; Dutordoir et al., 2016). After excluding units, shelf filings, and issues by utilities (SIC codes 4900 to 4999) and financial firms (SIC codes 6000 to 6999 ) we have 2608 observations on issues used to finance investment. The second data source is Dealscan's bank loan data for U.S. industrial firms between 1995 and 2017. Dealscan also includes information on the use of proceeds and we obtain observations on 872 bank loans for which the reported use of proceeds is capital expenditure.

We supplement our sample of issues reported as being undertaken to finance capital expenditure with instances where, although the issuer states that the intention is to use the financing for "general corporate purposes", the firm's financial statements are consistent with the amount raised actually being used to finance capex. There are 465 instances in which both the amount raised (obtained from Thomson One Banker SDC or Dealscan) and the reported capital expenditure (reported in Compustat) that firm-year exceed 5\% of lagged assets (also obtained from Compustat) and the difference between the Compustat capital expenditure amount and total issue proceeds is less than $1 \%$ of lagged assets.

To determine the characteristics of these investments, we search Factiva and the internet for news releases around the time of the issue announcement as well as in annual and quarterly reports (also in subsequent years), the issue prospectus, and SEC files S-3, 424B, and 8-K in the SEC Edgar database. Even issuers selecting capital expenditures as use of proceeds might refrain from providing more details as a result of the issuer not wishing to reveal proprietary information to competitors or preferring spending flexibility. For the cases where the use of proceeds is given as capital expenditure, we can find details of the investment for 568 public issues and 198 bank loans. For the 465 instances where the use of funds is reported as "general corporate purposes" but it is likely that the funds were used for investment, we can find details of the investment characteristics through company filings and news releases in 35 cases. ${ }^{11}$

When a firm issues a security in order to build financial slack and only later decides to invest in assets, the initial use of proceeds will not be listed as capital expenditure and these instances will not be included in our sample. MacKie-Mason (1990) points out that having observations on only a subset of financing options can raise econometric issues. ${ }^{12}$ As in MacKie-Mason (1990), the econometric analysis relies on a weak revealed preference restriction to measure the determinants of financing choices. Conditional on raising funds externally, a necessary and sufficient condition for optimization is that the observed choice adds more to the firm's objective function than the alternatives do. Note that we do not require that the investment be undertaken in the year of financing. This is an advantage compared to an analysis that relate the characteristics of investments to changes in the firm's capital structure in the year of the investment (Campello and Giambona, 2013).

In total, our sample consists of 801 capital raisings by 572 different firms where we can obtain details on the associated investments. ${ }^{13}$ These investments can be very broadly classified as aircraft and vessel purchases (10\%), development (13\%), drilling/ mining (6\%), business expansion (27\%), asset improvements (6\%), innovation/exploration (25\%), and equipment purchases (14\%).

\subsection{Investment characteristics}

Two Masters business students independently evaluated the details of the 801 investments. If their classifications of an investment's characteristics differed, then the study's authors determined the classification. Our approach of classifying investments by their characteristics can provide new insights, but it is labor intensive and harder to replicate. Any measurement error might bias against finding statistically significant results. The Appendix lists the classifications of the investment characteristics of 20 representative investments.

The classification of an investment as Tangible \& Non-unique involves the determination of whether the investment is in a tangible asset and whether that asset is redeployable. This allows for a comparison of the separate effects on financing of Tangible \& Non-unique investments versus Tangible \& Unique investments. An example of a tangible non-unique investment is the acquisition of trucks by Rollins Truck Leasing Corp. An example of a tangible but unique investment in our data set is the acquisition of equipment that

\footnotetext{
$\overline{10}$ Schedule A of the Securities Act of 1933 requires public issuers to disclose the specific purposes for which funds are being raised "so far as determinable." Where the main purpose is the acquisition of assets other than in the ordinary course of business, the assets must be briefly described.

${ }^{11}$ The results of our analysis of the link between financing and investment characteristics are robust to excluding the additional 35 observations obtained through our investigation of financings for "general corporate purposes."

12 One might attempt to study the characteristics of internally-financed investments by examining Compustat firm-years with capital expenditure and a similarly-sized total for a firm's free cash flow from operations less dividends and repurchases plus the decrease in a firm's financial asset holdings. Our attempts in this manner have not been successful largely because firms and the media rarely report details of internally-financed investments.

${ }^{13} 801=568+198+35$.
} 
produces Baxano Surgical's Avance Pedicle Screw System. This equipment has almost no alternate use and hence little collateral value. Similarly, tangible oil rigs have no alternate use beyond scrap and therefore have little collateral value.

The classification of an investment as having an $R \& D$-like characteristic occurs when the description of the investment in the issue prospectus, associated reports, or news releases uses terms like "R\&D", "innovation", and "exploration". Where possible, Investment Life is initially determined using Table 3 of Fraumeni (1997) cross-checked with information on expected service lives found through an internet search. ${ }^{14}$ Fraumeni (1997) reports information on the typical life spans of various asset types; e.g., 9 years for tractors, 20 years for aircraft, 32 years for steam engines, and 36 years for buildings. We search the internet for confirmation or adjustment of the values in Fraumeni (1997). For example, a KPMG report gives the useful life of aircraft acquired by major airlines as 20 to 25 years, ${ }^{15}$ and we use 22.5 years as our estimate of the average useful life of an aircraft. Although Fraumeni (1997) gives the service life of generic mining and oil field machinery as 10 years, the 10-K filing of a large drilling rig contractor, Transocean, reports that the average useful life of drilling platforms as 26.5 years and we select this number as the life of drilling platform investment. ${ }^{16}$ Investments in new products are assigned much shorter life spans. Given the lack of barriers to entry in the marketing of over-the-counter pharmaceuticals, the investment to launch a new head lice product by TyraTech Inc. was assigned a three-year life. ${ }^{17}$ The average (median) maturity of investments in our sample is 11.37 (10) years.

The Time until Payoffs characteristic indicator is tri-valued and distinguishes between investments whose positive payoffs are expected to begin within one year of the investment, after one year but within five years, or after more than five years. As examples, the expected time until positive payoffs is classified as high (assigned an indicator value of two) for Vion Pharmaceuticals' funding of preclinical trials, as medium for Sotheby's expansion of its New York headquarters (an indicator value of one), and as short for an investment to improve the efficiency of Vision Sciences process for manufacturing endoscopic products (an indicator value of zero).

Investment Life Uncertainty is classified using a zero-one indicator. As examples, the payoffs from an investment by Brainstorm Cell Therapeutics' in research and development and clinical trials are classified as having a relatively uncertain lifespan (an indicator value of one), while the life of the payoffs from Hornbeck Offshore Services' construction of ocean-going tugs is comparatively certain (an indicator value of zero). The Volatility indicator is a measure of the risk of the investment. In terms of payoff uncertainty, the payoffs from Pixelworks' development of multimedia projector, high-end television, and mobile devices are classified as volatile (an indicator value of one), while the payoffs from Javo Beverage's purchase of dispensing equipment are classified as not being volatile (an indicator value of zero).

The tri-valued Need for Monitoring indicator is based on an assessment of the potential for suboptimal exercise of the continuation, expansion, and abandonment options implicit in an investment. T-Mobile's "opportunistically acquiring of additional spectrum in private party transactions" 18 is assigned as having a high need for monitoring (an indicator of two). In contrast, Target Corporation's construction of a new store is assigned an indicator score of one and a purchase of machinery to service existing demand is assigned the low score of zero.

\section{Data analysis}

We examine the investment characteristics and financing of the 801 investments in our sample. In total, 286 of the investments are financed by issuing debt, 473 by issuing equity, and 42 by a convertible issue. The relatively large proportion of equity issues in the sample might be due to greater press interest in equity issues, thereby making it more likely that we are able to find information on the details of the investment. We examine a potential sample selection bias in Section 5 .

We first analyze the debt-equity choice for the 759 investments financed by either straight debt or common stock. Panel A of Table 1 presents descriptive statistics on the characteristics of these investments. Panel B reports a univariate analysis of the link between the financing choice and the investments' characteristics. The average estimated life of investments financed by debt issues is significantly longer than that of equity-financed investments and assets that are both tangible and non-unique are substantially more likely to be financed by a debt issue. Rounding to two decimal places, 0.61 of our sample of externally-financed investments involve tangible assets and 0.30 involve non-unique assets. The fraction of investments that are both tangible and non-unique also rounds to 0.30 . Thus, almost every investment that is non-unique is also tangible. Fully 231 of the 234 investments in non-unique assets are tangible; i.e., tangibility and uniqueness are far from independent.

Of debt-financed investments, only $6 \%$ can be classified as R\&D projects, whereas $40 \%$ of equity-financed investments can be so classified. While 13\% for debt-financed investments have an uncertain life, 53\% of equity-financed projects have an uncertain life. Equity-financed investments have significantly more volatile payoffs, a significantly lower need for monitoring, and a significantly higher time until positive payoffs are first expected. The differences between the characteristics of investments financed by debt and those financed by equity are statistically significant at the $1 \%$ level for each individual investment characteristic. Panel B also reports univariate analyses of the link between the financing choice and the set of control variables discussed in Section 2.2 . In every case, the

\footnotetext{
14 In some instances, we used the depreciable life of an investment for tax purposes. See, for example, https://www.irs.gov/publications/p946, https://www.ird.govt.nz/resources/5/b/5ba3ca804ba3cf79886cbd9ef8e4b077/ir267.pdf and https://www.ird.govt.nz/resources/3/0/303acb9bf2df-4267-bdb9-b22e3f983889/ir265.pdf.

15 https://www.kpmg.com/Global/en/IssuesAndInsights/ArticlesPublications/Documents/components-of-aircraft-acquisition.pdf.

16 http://www.sec.gov/Archives/edgar/data/1083269/000108326909000003/0001083269-09-000003.txt.

17 http://www.proactiveinvestors.co.uk/companies/news/55311/tyratech-raises-19mln-for-vamousse-head-lice-launch-65416.html.

18 See http://investor.t-mobile.com/File/Index?KeyFile=20888515.
} 
Table 1

Descriptive statistics. Descriptive statistics for the 759 investments financed by either straight debt or equity. Panel A reports means, medians and standard deviations. Estimated life is in years. The variables Tangible \& Non-unique, Tangible, Unique, R\&D, Investment Life Uncertainty, and Volatility are zero-one dummies. The Time until Payoffs and Need for Monitoring variables are tri-valued indicators ranging from zero to two. Firm HOT is a measure of the deviation from target leverage when issuing debt vs equity and is the projected difference between the absolute deviation from target leverage if the firm issues debt and the absolute deviation from target leverage if the firm issues equity. A positive value of this variable indicates that a firm would end up closer to its target leverage ratio if it issues equity rather than debt. Target leverage is the predicted value after estimating a regression of book leverage on lagged values of firm size, profitability, tangibility, market-to-book ratio, depreciation, R\&D expenses, a dummy indicating whether the firm reports R\&D expenses, industry median book leverage, and expected inflation for all industrial Compustat firms over the 1995-2017 period. Deviation from industry leverage when issuing debt vs equity is the projected difference between the absolute deviation from industry median leverage if the firm issues debt and the absolute deviation from industry median leverage if the firm issues equity. Industries are based on the Fama-French 12 industry classification. Firm Stock Performance is the stock return over trading days -252 to -2 relative to the issue date. Firm Book Leverage, Firm MB, Firm R\&D/Sales, and MV Equity are measured at the end of the financial year preceding the issue. Firm variables are winsorized at the $2.5 \%$ level at both tails. Panel B presents a univariate analysis of the distinction between investments financed by debt and investments financed by equity. For dummy variables we calculate whether the difference between two proportions is significant using a twoproportion $z$-test. For the other variables we calculate difference of means $t$-statistics with a $t$-test that does not assume equal variances. Panel $C$ presents pairwise correlation coefficients. $* * *, * *$ and *indicate statistical significance at the $1 \%, 5 \%$ and $10 \%$ level, respectively.

\begin{tabular}{|c|c|c|c|c|c|c|c|c|c|}
\hline \multicolumn{4}{|l|}{ Panel A } & $\mathrm{N}$ & \multicolumn{2}{|l|}{ Mean } & \multicolumn{2}{|l|}{ Median } & Standard deviation \\
\hline \multicolumn{4}{|l|}{ Tangible } & 759 & \multicolumn{3}{|l|}{0.61} & & \\
\hline \multicolumn{4}{|l|}{ Unique } & 759 & \multicolumn{3}{|l|}{0.70} & & \\
\hline \multicolumn{4}{|l|}{ Tangible \& Non-unique } & 759 & \multicolumn{3}{|l|}{0.30} & & \\
\hline \multicolumn{4}{|l|}{$R \& D$} & 759 & \multicolumn{3}{|l|}{0.27} & & \\
\hline \multicolumn{4}{|l|}{ Investment Life } & 759 & \multicolumn{2}{|l|}{11.37} & 10.00 & & 6.78 \\
\hline \multicolumn{4}{|l|}{ Time until Payoffs } & 759 & \multicolumn{2}{|l|}{1.07} & & & \\
\hline Investment Life Uncer & & & & 759 & 0.38 & & & & \\
\hline Volatility & & & & 759 & 0.82 & & & & \\
\hline Need for Monitoring & & & & 759 & 0.90 & & & & \\
\hline Firm HOT & & & & 680 & 0.12 & & 0.07 & & 0.20 \\
\hline Deviation from indu & verage when issu & bt vs equ & & 680 & 0.15 & & 0.11 & & 0.19 \\
\hline Firm Book Leverage & & & & 680 & 0.23 & & 0.17 & & 0.25 \\
\hline Firm $M B$ & & & & 680 & 2.92 & & 1.95 & & 2.38 \\
\hline Firm Stock Performar & & & & 680 & 0.40 & & 0.08 & & 0.98 \\
\hline Firm $R \& D /$ Sales & & & & 680 & 0.24 & & 0.00 & & 0.39 \\
\hline Firm Proceeds/MV Ec & & & & 680 & 0.25 & & 0.14 & & 0.35 \\
\hline Panel B & & & & Debt issues & & Equity issues & & Differen & ce of means statistic \\
\hline Tangible & & & & 0.91 & & 0.42 & & $13.24^{* *}$ & \\
\hline Unique & & & & 0.45 & & 0.85 & & -11.86 & \\
\hline Tangible \& Non-uniq & & & & 0.55 & & 0.14 & & $11.76^{* *}$ & \\
\hline$R \& D$ & & & & 0.06 & & 0.40 & & -10.28 & \\
\hline Investment Life & & & & 13.66 & & 9.98 & & $6.65 * * *$ & \\
\hline Time until Payoffs & & & & 0.73 & & 1.27 & & $-12.65^{*}$ & \\
\hline Investment Life Uncer & & & & 0.13 & & 0.53 & & $-11.04 *$ & \\
\hline Volatility & & & & 0.64 & & 0.92 & & $-9.61^{* *}$ & \\
\hline Need for Monitoring & & & & 0.80 & & 0.96 & & $-4.24^{* *}$ & \\
\hline Firm HOT & & & & 0.05 & & 0.16 & & $-8.85^{* *}$ & \\
\hline Deviation from indu & verage when issu & bt vs equ & & 0.07 & & 0.20 & & $-9.73^{* *}$ & \\
\hline Firm Book Leverage & & & & 0.31 & & 0.18 & & $6.56^{* * *}$ & \\
\hline Firm $M B$ & & & & 1.88 & & 3.56 & & $-10.78 *$ & \\
\hline Firm Stock Performar & & & & 0.16 & & 0.55 & & $-5.60^{* *}$ & \\
\hline Firm R\&D/Sales & & & & 0.14 & & 0.29 & & $-5.51^{* *}$ & \\
\hline Firm Proceeds/MV Ec & & & & 0.21 & & 0.27 & & $-2.32^{* *}$ & \\
\hline Panel C & $\begin{array}{l}\text { Tangible \& Non- } \\
\text { unique }\end{array}$ & $R \& D$ & $\begin{array}{l}\log \text { (Investment } \\
\text { Life) }\end{array}$ & $\begin{array}{l}\text { Time until } \\
\text { Payoffs }\end{array}$ & & $\begin{array}{l}\text { Investment Life } \\
\text { Uncertainty }\end{array}$ & & Volatility & $\begin{array}{l}\text { Need for } \\
\text { Monitoring }\end{array}$ \\
\hline Tang \& Non-U & 1.00 & & & & & & & & \\
\hline$R \& D$ & -0.39 & 1.00 & & & & & & & \\
\hline $\log ($ Investment Life $)$ & 0.47 & -0.24 & 1.00 & & & & & & \\
\hline Time until Payoffs & -0.24 & 0.52 & 0.10 & 1.00 & & & & & \\
\hline $\begin{array}{l}\text { Investment Life } \\
\text { Uncertainty }\end{array}$ & -0.42 & 0.71 & -0.20 & 0.59 & & 1.00 & & & \\
\hline Volatility & -0.24 & 0.29 & 0.22 & 0.45 & & 0.37 & & 1.00 & \\
\hline Need for Monitoring & -0.10 & 0.36 & 0.15 & 0.55 & & 0.37 & & 0.44 & 1.00 \\
\hline
\end{tabular}


control variables are significantly related to the debt-equity choice in the predicted manner.

Panel C reports the correlations between the characteristics. ${ }^{19}$ The Investment Life Uncertainty and Time until Payoffs are positively correlated. The $R \& D$ indicator is positively correlated with both Investment Life Uncertainty and the Time until Payoffs. The Tangible \& Non-unique indicator is negatively associated with Investment Life Uncertainty and positively associated with the Investment Life. The high correlations highlight the importance of our simultaneous examination of investment characteristics rather than a focus on a single investment characteristic.

Table 2 uses a logistic regression to investigate the relation between the debt-equity choice and investment characteristics. The results without firm-level controls are reported in column (1). Standard errors are clustered at the issuer level. Observations on control variables that are in the $2.5 \%$ tails are set equal to the corresponding value at the $2.5 \%$ or $97.5 \%$ cutoff.

Tangible \& Non-unique (i.e., high collateral value) investments are significantly more likely to be financed with debt. As explained in Section 2.1, a positive link between collateral value and debt financing is in line with the predictions of both trade-off theory and predictions based on informational asymmetries. Because debt can create an overhang problem, firm value can be diminished if multistage $R \& D$ projects are financed by debt and we see that $R \& D$-like investments are significantly more likely to be financed with equity.

Section 2.1 observes that the relation between Investment Life and the financing choice is unclear. The multivariate analysis of Table 2 fails to find a statistically significant effect of Investment Life on the choice between debt and equity financing, whereas the univariate analysis in Table IB reports a significant positive relation between Investment Life and debt financing. The difference between the multivariate and univariate results is likely because long-lived assets are more likely to be Tangible \& Non-unique (the correlation coefficient is 0.47 ) and hence the univariate relation between Investment Life and debt financing is positive.

As predicted in Section 2.1, Time until Payoffs is significantly positively related to the likelihood of an investment being equityfinanced. To our knowledge, ours is the first empirical demonstration of this relation. An increase in the Time until Payoffs from less than a year to between one and five years or from between one and five years to greater than five years increases the odds of observing equity-financing by a factor of $\mathrm{e}^{1.49}=4.44$ in a logit analysis that does not include control variables (column (1) of Table 2) and by a factor of $\mathrm{e}^{1.32}=3.74 \mathrm{in}$ an analysis with six control variables and industry and period dummies (column (4) of Table 2).

Section 2.1 argues that the likelihood of equity financing is increasing with Investment Life Uncertainty. We do not find a statistically significant positive effect of Investment Life Uncertainty on the likelihood of issuing equity, even though our univariate analysis indicated that $53 \%$ of investments financed by equity have lives that are highly uncertain while only $13 \%$ of investments financed by debt have highly uncertain lives. An explanation may be the exceptionally strong correlations between Investment Life Uncertainty and variables such as the $R \& D$ indicator (correlation coefficient of 0.71) and Time until Payoffs (correlation coefficient of 0.59). These strong correlations point to the importance of the factor analysis that is conducted in Section 6 .

Also as predicted in Section 2.1, the likelihood of equity financing is positively related to the investment's payoff Volatility. The relation is statistically significant at the $1 \%$ level. High volatility means a higher chance of bankruptcy if the investment is debtfinanced and thus a higher chance of a stockholder-bondholder coordination problem if poor performance is associated with firm restructuring. Finally, consistent with debtholders' relative better monitoring ability compared to that of diffused shareholders and/or debtholders' ability to incorporate restrictions into debt covenants, we find that an increased Need for Monitoring decreases the likelihood of equity financing and that this observed negative relation is statistically significant at the $1 \%$ level.

In summary, Section 2.1 makes predictions concerning the link between six of the seven investment characteristics and the debtequity choice. In all six cases the estimated coefficient has the correct sign and is statistically significant for five of the six. Section 2.1 makes no prediction concerning the relation between a seventh investment characteristic, Investment Life, and the debt-equity choice and we do not observe a significant coefficient on this characteristic.

Column (2) of Table 2 reports the results when the controls discussed in Section 2.2 are included. Information from Compustat and CRSP is required to calculate the controls and their inclusion reduces our sample size from 759 to 680 observations with the majority of lost observations involving equity issues. The proxy for target leverage used in constructing the Firm HOT control measure in Table 2 is the predicted leverage based on a regression of book leverage on lagged firm size, profitability, tangibility, market-to-book ratio, depreciation, R\&D expenses, a dummy equal to one when the firm reports R\&D expenses, industry median book leverage, and expected inflation. ${ }^{20}$ Equity issues are significantly more likely when a debt issue would move the firm further away from its estimated target leverage than an equity issue would. The negative coefficient on Firm Book Leverage at the end of the prior financial year indicates that firms that have shunned debt in the past continue to do so, in line with the persistence of capital structure choices documented in Lemmon et al. (2008). ${ }^{21}$ Consistent with market timing theory, equity issues are significantly more likely when management is more likely to perceive equity as overvalued; i.e., when a firm's market-to-book ratio is high and/or after a firm's prior year Firm Stock Performance has been high (Baker and Wurgler, 2002; Warusawitharana and Whited, 2016). The significant positive relation between Firm $M B$ and equity financing is also consistent with Firm MB being a proxy for investment opportunities (Adam and Goyal, 2008) and a

\footnotetext{
19 In computing the correlations, we use the natural logarithm of the life of the investment. This is the form in which the variable is employed in the regression analysis.

${ }^{20}$ None of the results change in sign or significance if instead the Firm HOT measure is calculated by using industry median leverage as the proxy for target leverage.

21 Since the use of book leverage at the end of the prior financial year as a linear control may not appropriately capture the possibility that some firms are committed to very high or very low leverage, the analysis of Table 2 was repeated on the subset of observations where the prior year's leverage was between 0.1 and 0.9. All conclusions remain unchanged.
} 


\section{Table 2}

Logit analysis of the debt-equity issue determinants. Logit analysis of the debt-equity choice. The dependent variable is a dummy equal to one for equity issues and zero for straight debt issues. See Table 1 for a description of the explanatory variables. Industry dummies are based on the FamaFrench 12 industry classification. Period dummies are based on five-year intervals. Heteroskedasticity-consistent standard errors clustered at the issuer level are reported in parentheses. $* * *, * *$ and *indicate statistical significance at the $1 \%, 5 \%$ and $10 \%$ level, respectively.

\begin{tabular}{|c|c|c|c|c|c|}
\hline Characteristics & Prediction & (1) & (2) & (3) & (4) \\
\hline Tangible \& Non-unique & - & $\begin{array}{l}-1.18^{* * *} \\
(0.29)\end{array}$ & $\begin{array}{l}-1.18^{* * * *} \\
(0.34)\end{array}$ & $\begin{array}{l}-1.07^{* * *} \\
(0.37)\end{array}$ & $\begin{array}{l}-1.31^{* * *} \\
(0.40)\end{array}$ \\
\hline$R \& D$ & + & $\begin{array}{l}0.90 * * \\
(0.46)\end{array}$ & $\begin{array}{l}0.55 \\
(0.53)\end{array}$ & $\begin{array}{l}0.51 \\
(0.59)\end{array}$ & $\begin{array}{l}-0.01 \\
(0.61)\end{array}$ \\
\hline $\log ($ Investment Life $)$ & ? & $\begin{array}{l}-0.39 \\
(0.26)\end{array}$ & $\begin{array}{l}-0.16 \\
(0.29)\end{array}$ & $\begin{array}{l}-0.50 \\
(0.32)\end{array}$ & $\begin{array}{l}-0.84^{* *} \\
(0.35)\end{array}$ \\
\hline Time until Payoffs & + & $\begin{array}{l}1.49 * * * \\
(0.31)\end{array}$ & $\begin{array}{l}1.57^{* * *} \\
(0.35)\end{array}$ & $\begin{array}{l}1.44 * * * \\
(0.36)\end{array}$ & $\begin{array}{l}1.32^{* * *} \\
(0.36)\end{array}$ \\
\hline Investment Life Uncertainty & + & $\begin{array}{l}0.13 \\
(0.39)\end{array}$ & $\begin{array}{l}0.26 \\
(0.40)\end{array}$ & $\begin{array}{l}0.35 \\
(0.41)\end{array}$ & $\begin{array}{l}-0.43 \\
(0.44)\end{array}$ \\
\hline Volatility & + & $\begin{array}{l}1.29 * * * \\
(0.35)\end{array}$ & $\begin{array}{l}1.22^{* * *} \\
(0.38)\end{array}$ & $\begin{array}{l}1.29 * * * \\
(0.38)\end{array}$ & $\begin{array}{l}1.37 * * * \\
(0.38)\end{array}$ \\
\hline Need for Monitoring & - & $\begin{array}{l}-0.98^{* * *} \\
(0.31)\end{array}$ & $\begin{array}{l}-0.74^{* *} \\
(0.32)\end{array}$ & $\begin{array}{l}-0.67^{* *} \\
(0.34)\end{array}$ & $\begin{array}{l}-0.41 \\
(0.32)\end{array}$ \\
\hline \multicolumn{6}{|l|}{ Control variables } \\
\hline Firm HOT & + & & $2.86^{* * *}(1.08)$ & $3.56^{* * *}(1.22)$ & $2.75^{* *}(1.17)$ \\
\hline Firm Book Leverage & - & & $-1.29 * *(0.54)$ & $-1.93^{* * *}(0.60)$ & $-1.54 * *(0.61)$ \\
\hline Firm $M B$ & + & & $0.21 * *(0.09)$ & $0.23^{* *}(0.10)$ & $0.29 * * *(0.09)$ \\
\hline Firm Stock Performance & + & & $0.52 * * *(0.19)$ & $0.52^{* * *}(0.17)$ & $0.60 * * *(0.18)$ \\
\hline Firm R\&D/Sales & + & & $-0.32(0.41)$ & $-0.08(0.47)$ & $-0.04(0.47)$ \\
\hline Firm Proceeds/MV Equity & + & & $0.21(0.47)$ & $0.22(0.51)$ & $0.52(0.51)$ \\
\hline Industry dummies & & No & No & Yes & Yes \\
\hline Period dummies & & No & No & No & Yes \\
\hline$N$ & & 759 & 680 & 680 & 680 \\
\hline Pseudo $R^{2}$ & & 0.28 & 0.39 & 0.42 & 0.48 \\
\hline
\end{tabular}

desire to avoid future debt overhang problems. Neither Firm R\&D/Sales nor Firm Proceeds/MV Equity are significantly related to the likelihood of financing with equity.

Importantly, except for the $R \& D$ characteristic measure, the effects of investment characteristics on the debt-equity choice are robust to the inclusion of control variables. The coefficient on the $R \& D$ characteristic measure loses its statistical significance in Model 2. The pseudo $R^{2}$ of Model 2 is 0.39 . If we do not include the investment characteristics in the regression specification, the pseudo $R^{2}$ decreases to 0.18 (untabulated). This reduction in the fit of the model is significant at the $1 \%$ level and shows that investment characteristics are important determinants of the form of external financing.

We now turn to the economic significance of the investment characteristics as explanators of the debt-equity choice when control variables are included. Consider first the marginal effect when an indicator characteristic is one rather than zero and all the other explanatory variables are equal to their mean values. An equity issue is $19.3 \%$ less likely when the investment is Tangible \& Non-unique; $13.5 \%$ more likely when the investment is $R \& D$-like; and $14.9 \%$ more likely when the investment's payoffs have high Volatility. The marginal effect of high Investment Life Uncertainty is less than 1\%. A one standard deviation increase in the $\log ($ Investment Life) from its mean holding constant all other variables at their respective means, reduces the likelihood of an equity issue by approximately $2.4 \%$. The Need for Monitoring and the Time until Payoffs are tri-valued variables. We calculate their marginal effects as the average of the marginal effects of changing the variable from zero to one and from one to two, again holding all the other independent variables equal to their respective means. A one unit increase in the Need for Monitoring variable reduces the likelihood of an equity issue by $12.6 \%$. A one unit increase in the Time until Payoffs variable increases the likelihood of an equity issue by $29.9 \%$.

Column (3) of Table 2 includes industry fixed effects, with industries defined by the Fama-French 12 industry classification. To the extent that investments by firms in a given industry have similar characteristics, the inclusion of industry controls will bias against finding that investment characteristics are significantly related to the debt-equity choice. Still, the conclusions with industry fixed effects 3 are similar to those when the relation is investigated without industry controls. Column (4) includes both industry dummies and time dummies based on the period of the securities issuance. We distinguish between 1995 and 1999 (12\% of observations), 2000-2004 (21\% of observations), 2005-2009 (24\% of observations), $2010-2014$ (16\% of observations), and the remaining three years (27\% of observations) of our sample period. Our conclusions are unchanged except that the association between the debt-equity choice and Investment Life becomes statistically significant, while the association between the debt-equity choice and Need for Monitoring measure becomes statistically insignificant. The strongest and the most consistent effects across the various specifications reported in Table 2 are those associated with the investment characteristics Tangible \& Non-unique, Time until Payoffs, and Volatility.

The capital structure literature considers further determinants of target leverage and the debt-equity choice in addition to the controls included in column (4) of Table 2. These additional determinants include log(firm age), stock return volatility, a dummy equal to one for firms with net-operating loss carryforwards, log(assets), a firm's credit rating, Altman's z-score, cash holdings over total assets, SG\&A expenses over total assets, and a dummy equal to one for firms with insufficient internal funds, i.e. where the capital 
raised for investment exceeds the available cash and cash equivalents. Directly including the full set of these additional controls in the regression specification in Table 2 is hampered by the limited sample size. We therefore enter these additional controls singly as alternate variants of Control $k$ in regression (1). While an omitted variables bias can never be ruled out, it bears pointing out that when each of the alternate variants of Control $k$ are included in regression (1), the sign and significance of the coefficients on the seven investment characteristics measures remain unchanged. In addition, we estimate the regression specification with interaction terms added between investment characteristics and the dummy variable on having insufficient internal funds. We find that 6 of the 7 interaction terms do not have statistically significant effects. The one case in which the insufficiency of internal funds affects the relation between an investment characteristic and the external financing choice is for the variable log(investment life), where the interaction term is negative, in line with a relevance of a firm's debt capacity as predicted in Section 3.2. Overall, these additional results suggest that the availability of internal funds does not strongly affect the observed relations between investment characteristics and the external financing choice. The results are available upon request.

We extend the logistic regression of column (4) of Table 2 to demonstrate that tangibility alone does not give rise to collateral value and is not in itself sufficient to facilitate debt financing. We do so by adding an indicator of whether an asset is both tangible and unique as an additional explanatory variable in the regression. This allows us to examine the separate effects of tangible, unique investments (those with little collateral value) and tangible, non-unique investments (those with high collateral value) on the financing choice. Table 3 shows the results. The estimated coefficient on the Tangible \& Unique characteristic is -0.93 , which is just significant at the $10 \%$ level. The coefficient on the Tangible \& Non-unique characteristic is more than twice as negative $(-2.06)$ and is significant at the $1 \%$ level. The difference between the two coefficients is significant at the $1 \%$ level, with an associated $\chi^{2}$ statistic of 7.66 . Thus, we conclude that investments with high collateral value are significantly more likely to be debt-financed than otherwise equivalent tangible investments that are not redeployable.

Not only can there be a link between investment characteristics and the choice between debt and equity when an investment is externally financed, an interesting link might also exist between investment characteristics and the identity of the buyer of the new issue. For example, the need for monitoring could influence whether an equity issue is placed with a blockholder or sold diffusively. Perhaps most important in terms of monitoring is the distinction between debt capital provided by banks and debt capital supplied by public investors. ${ }^{22}$ Table 4 first presents a univariate analysis of the distinction between investments financed by public debt and investments financed by bank loans. The univariate analysis in Panel A shows, for instance, that investments financed with public debt issues on average have a higher time before payoffs than those financed by bank loans. In Panel B we analyze the choice between financing with equity, with public debt, and via a bank loan with a multinomial logit model. We use a multinomial logit model as a Hausman test does not reject the independence of irrelevant alternatives assumption for the three choices. We find that the relation between investment characteristics and the choice between equity and bank debt financing is in many ways similar to that for the choice between equity and public debt financing. One point of difference between the results of Tables 2 and 4 concerns the coefficient on the Need for Monitoring variable. The Need for Monitoring is significantly positively related to financing with public debt rather than with equity (column (3) of Table 4) and is not significantly related to the choice between bank debt versus equity financing (column (4) of Table 4).

The other difference between the Tables concerns the coefficient on the $R \& D$ characteristic. While $R \& D$ is not significantly related to either the debt-equity choice per se (column (4) of Table 2) or the choice between financing with bank debt versus equity (column (4) of Table 4), it is significantly and positively related to the likelihood of issuing equity rather than public debt (column (3) of Table 4). When a sequence of investments, as in $R \& D$, is financed by a series of short-term debt issues, there is no debt overhang and success on the first stage can more cleanly determine the continuation decision. In our sample, bank debt typically has a shorter life than public debt. Fully $75 \%$ of our bank debt has a life of less than six years, while only $30 \%$ of the public debt has a similarly short life. Similarly, $40 \%$ of the bank debt and only $19 \%$ of the public debt matures in less than four years. The longer lives of the public debt issues make public debt a less attractive method of financing sequential investments.

\section{Heckman two-stage sample selection model}

For the 3945 issues undertaken to finance capital expenditures, we were able to find details of the investments' characteristics in only approximately one fifth of cases. Thus, sample selection bias could be problematic for the interpretation of our results if the firm's debt-equity choice and the likelihood of either the firm or the financial press reporting details on the use of the new issue's proceeds are determined by a common set of unobservable determinants that are also correlated with investment characteristics (Heckman, 1979; Dutordoir et al., 2017). To examine the effects of a potential selection bias in the sample of investments we are able to characterize, we use the two-stage Heckman regression technique, adjusted for a binary dependent variable. In the first stage, we estimate a probit model of the probability that a firm or the press reports details on an investment, and in the second stage we estimate a probit model of the debt-equity choice in financing that investment. The estimation of the first stage of the model results in an inverse Mill's ratio, which serves as control for sample selection bias in the second stage.

Our first-stage specification includes as explanatory variables the set of control variables that are also used in the second stage plus two instruments for the probability of reporting. The instruments are the reputation of the investment bank and the industry-year norm

\footnotetext{
$\overline{22}$ There is a large literature on differences between financing with bank debt versus with public debt (Rajan, 1992; Denis and Mihov, 2003; de Fiore and Uhlig, 2011). Our sample of public debt includes 18 observations that Thomson One Banker's SDC flags as 144A issues. Excluding these 18 issues leaves our conclusions unchanged.
} 
Table 3

Tangibility and uniqueness. Logit analysis of the debt-equity choice as in Model 4 of Table 2 with the variable Tangible \& unique added to the set of explanatory variables in the regression specification. The variable Tangible \& unique is a zeroone dummy equal to one when the investment is classified as both tangible and unique. The dependent variable is a dummy equal to one for equity issues and zero for straight debt issues. See Table 1 for a description of the other explanatory variables. We only report the coefficients for the variables Tangible \& non-unique and Tangible \& unique. ***, ** and *indicate statistical significance at the $1 \%, 5 \%$ and $10 \%$ level, respectively.

\begin{tabular}{ll}
\hline Characteristics & Debt versus equity \\
\hline Tangible \& non-unique & $-2.06^{* * *}$ \\
Tangible \& unique & $(0.55)$ \\
$\chi^{2}$ for difference between coefficients & $-0.93^{*}$ \\
\hline
\end{tabular}

of providing information. Higher reputation underwriters are expected to be associated with better information provision without having a strong direct link to the debt-equity choice and we use the list of the 15 most reputable investment banks from Fang (2005). The industry-year norm of providing information follows Anderson et al. (2012). ${ }^{23}$ We calculate the industry-year norm as the log of one plus the percentage of equity issuers in a Fama-French 12 industry-year that report a specific principle use of the issue proceeds in SDC (i.e., a use of proceeds such as "capital expenditures", "refinancing", or "future acquisitions", rather than simply "general corporate purposes"). We expect that a high industry norm of being more specific is associated with a higher likelihood of providing details on an investment's characteristics. When the two-stage model is estimated for our full debt-equity sample we use only the industry-year norm instrument since the underwriter variable is not applicable to bank loans. We use both instruments when estimating the two-stage model for a sample excluding bank loans.

The results are contained in Table 5. Panel A presents a univariate comparison between securities issued for capital expenditure purposes where firms do not provide details on these capital expenditures and securities issued for capital expenditure purposes where firms do provide details on these capital expenditures. We find that in the sample without details $49 \%$ of observations are equity issues, whereas in the sample with details on investments this percentage increase to $62 \%$, which is in line with equity issuers being more likely to provide more information. Several firm-level control variables are statistically different between both samples, and some remain to be different in the first stage of the multivariate analysis in Panel B. More specifically, details are more likely to be provided when stock performance is good, the market-to-book ratio is high, and proceeds are a larger fraction of the firm's market value. The main purpose of Panel B is to examine whether this selection bias affects our conclusions. The first-stage probit results show that a high industry norm and the reputation of the investment bank, which we use as instruments, are strongly associated with a higher likelihood of providing details on an investment's characteristics. ${ }^{24}$ Importantly, the conclusions on the effects of the investment characteristics in the second-stage regression are similar to those drawn from Table 2. The strongest effects are that investments with high Volatility and investments with high Time until Payoffs are more likely to be financed by equity, whereas Tangible \& Non-unique investments and investments with a high Need for Monitoring are more likely to be financed by debt. These findings suggest that our results are robust to sample selection bias resulting from heterogeneous information provision across firms and are not driven by an overrepresentation of equity issues in our sample.

\section{Factor analysis}

Investment characteristics are not orthogonal determinants of the financing choice. Both the high correlations between the investment characteristics (Panel C of Table 1) and the benefits of considering a smaller number of variables make a factor analysis interesting. Table 6 reports the results of a factor analysis of the investment characteristics using the principal factor method. ${ }^{25}$ The analysis identifies three principal dimensions along which investments differ.

The eigenvalue of a factor is a measure of the variation in all the characteristics accounted for by that factor. By construction, the first factor contributes most to the explanation of variation in the characteristics. In our analysis, the first factor explains $69 \%$ of the total variation that is explained by the main three factors. The eigenvalues of the second and third factors are close to or below one, which indicates that they do not explain much more of the variation than is explained by a single characteristic. We therefore focus on

\footnotetext{
$\overline{23}$ Anderson et al. (2012) use the Heckman sample selection procedure for their analysis of R\&D expenses, which are often not reported by firms. Appendix A of their paper provides a detailed explanation of the procedure. See also Guedes and Opler (1996).

${ }^{24}$ The first stage regression of the debt-equity choice involves 1643 debt-financed observations and 1763 equity-financed observations, whereas the first stage regression of the choice between public debt and equity regression (where we require information on the investment bank) involves 492 public debt-financed observations and 1588 equity-financed observations.

${ }^{25}$ See Lattin et al. (2003).
} 


\section{Table 4}

Multinomial logit analysis of the choice between equity, public debt, and bank debt. This table compares common equity issues, public debt issues, and bank loans. Panel A presents a univariate analysis of the distinction between investments financed by public debt and investments financed by bank loans. Panel B reports a multinomial logit analysis. The dependent variable has a separate value for common equity issues, public debt issues, and bank loans. We use a common equity issue as the pivot outcome in our estimation. See Table 1 for a description of the explanatory variables. Industry dummies are based on the Fama-French 12 industry classification. Period dummies are based on five-year intervals. Heteroskedasticityconsistent standard errors clustered at the issuer level are reported in parentheses. $* * * * *$ and $*$ indicate statistical significance at the $1 \%, 5 \%$ and $10 \%$ level, respectively.

\begin{tabular}{|c|c|c|c|c|}
\hline \multicolumn{2}{|l|}{ Panel A } & Public Debt issues & Bank loans & Difference of means statistic \\
\hline \multicolumn{2}{|l|}{ Tangible } & 0.79 & 0.95 & $-4.01 * * *$ \\
\hline \multicolumn{2}{|l|}{ Unique } & 0.28 & 0.50 & $-3.35 * * *$ \\
\hline \multicolumn{2}{|l|}{ Tangible \& Non-unique } & 0.69 & 0.50 & $2.94 * * *$ \\
\hline \multicolumn{2}{|l|}{$R \& D$} & 0.01 & 0.07 & $-1.80^{*}$ \\
\hline \multicolumn{2}{|l|}{ Investment Life } & 15.00 & 13.21 & $1.81^{*}$ \\
\hline \multicolumn{2}{|l|}{ Time until Payoffs } & 0.94 & 0.66 & $3.95 * * *$ \\
\hline \multicolumn{2}{|l|}{ Investment Life Uncertainty } & 0.18 & 0.12 & 1.38 \\
\hline \multicolumn{2}{|l|}{ Volatility } & 0.67 & 0.64 & 0.48 \\
\hline \multicolumn{2}{|l|}{ Need for Monitoring } & 1.07 & 0.71 & $7.01 * * *$ \\
\hline \multicolumn{2}{|l|}{ Firm HOT } & 0.03 & 0.05 & -1.16 \\
\hline \multicolumn{2}{|c|}{ Deviation from industry leverage when issuing debt vs equity } & 0.06 & 0.07 & -0.91 \\
\hline \multicolumn{2}{|c|}{ Firm Book Leverage } & 0.40 & 0.28 & $4.14 * * *$ \\
\hline \multicolumn{2}{|l|}{ Firm $M B$} & 1.68 & 1.94 & -1.62 \\
\hline \multicolumn{2}{|l|}{ Firm Stock Performance } & 0.15 & 0.16 & -0.14 \\
\hline \multicolumn{2}{|l|}{ Firm $R \& D /$ Sales } & 0.03 & 0.18 & $-5.28 * * *$ \\
\hline \multicolumn{2}{|l|}{ Firm Proceeds/MV Equity } & 0.11 & 0.24 & $-3.67 * * *$ \\
\hline Panel B & Public debt versus equity & Bank debt versus equity & Public debt versus equity & Bank debt versus equity \\
\hline \multicolumn{5}{|l|}{ Characteristics } \\
\hline \multirow[t]{2}{*}{ Tangible \& Non-unique } & $1.75^{* * *}$ & $1.01^{* * *}$ & $2.51^{* * *}$ & $0.97^{* *}$ \\
\hline & $(0.46)$ & $(0.31)$ & $(0.74)$ & $(0.41)$ \\
\hline \multirow[t]{2}{*}{$R \& D$} & $-3.41^{* * *}$ & -0.27 & $-3.55^{* *}$ & 0.92 \\
\hline & $(1.09)$ & $(0.59)$ & $(1.47)$ & $(0.62)$ \\
\hline \multirow[t]{2}{*}{$\log ($ Investment Life $)$} & 0.62 & 0.37 & -0.37 & $1.16^{* * *}$ \\
\hline & $(0.45)$ & $(0.27)$ & $(0.56)$ & $(0.38)$ \\
\hline \multirow[t]{2}{*}{ Time until Payoffs } & $-1.13^{*}$ & $-1.54 * * *$ & $-1.55^{* *}$ & $-1.50^{* * *}$ \\
\hline & $(0.58)$ & $(0.31)$ & $(0.70)$ & $(0.39)$ \\
\hline \multirow[t]{2}{*}{ Investment Life Uncertainty } & 0.57 & -0.50 & 1.36 & 0.16 \\
\hline & $(0.62)$ & $(0.55)$ & $(0.86)$ & $(0.44)$ \\
\hline \multirow[t]{2}{*}{ Volatility } & $-1.98 * * *$ & $-1.07 * * *$ & $-1.34 * *$ & $-1.16^{* * *}$ \\
\hline & $(0.63)$ & $(0.34)$ & $(0.67)$ & $(0.38)$ \\
\hline \multirow[t]{2}{*}{ Need for Monitoring } & $2.72 * * *$ & 0.57 & $3.27 * * *$ & 0.06 \\
\hline & $(0.46)$ & $(0.35)$ & $(0.80)$ & $(0.35)$ \\
\hline Control variables & & & & \\
\hline Firm HOT & & & $-1.96(2.76)$ & $-2.54 * *(1.22)$ \\
\hline Firm Book Leverage & & & $2.84^{* * *}(0.99)$ & $1.23 *(0.65)$ \\
\hline Firm $M B$ & & & $-0.40 * *(0.19)$ & $-0.29 * * *(0.10)$ \\
\hline Firm Stock Performance & & & $-0.42 *(0.22)$ & $-0.62^{* * *}(0.21)$ \\
\hline Firm $R \& D /$ Sales & & & $-2.42 *(1.38)$ & $0.16(0.50)$ \\
\hline Firm Proceeds/MV Equity & & & $-3.39 * *(1.38)$ & $-0.29(0.51)$ \\
\hline Industry dummies & & & & es \\
\hline Period dummies & & & & es \\
\hline$N$ & & & & 80 \\
\hline Pseudo $R^{2}$ & & & & 48 \\
\hline
\end{tabular}


Table 5

Controlling for a potential selection bias. The relation between investment characteristics and the debt-equity choice using a Heckman two-stage model to control for sample selection bias. Panel A compares securities issued for capital expenditure purposes without details of these capital expenditures ("Not in sample") to those securities issued for capital expenditure purposes that provide details of these capital expenditures ("Sample"). Panel B reports a Heckman two-stage model. The first stage model is a probit with the dummy dependent variable equal to one when there is information about the investment's characteristics. The second stage is a probit model and its dummy dependent variable equals one for equity issues and zero for debt issues. Industry-year norm is the log of one plus the \% of equity issuers in a Fama-French 12 industry-year reporting a specific principle use of proceeds in SDC. Reputable Investment bank is a dummy for whether the underwriter is included in the top 15 in terms of market share (Fang, 2005). See Table 1 for a description of the explanatory variables. Standard errors are reported in parentheses. ***, ** and *indicate statistical significance at the $1 \%, 5 \%$ and $10 \%$ level, respectively.

\begin{tabular}{|c|c|c|c|c|}
\hline \multicolumn{2}{|l|}{ Panel A } & \multirow{2}{*}{$\begin{array}{l}\text { Not in sample } \\
0.49\end{array}$} & Sample & Difference of means statistic \\
\hline Percentage equity issues & & & 0.62 & $-7.15^{* * *}$ \\
\hline Firm HOT & & 0.08 & 0.12 & $-4.55^{* * *}$ \\
\hline Deviation from industry leve & g debt vs equity & 0.11 & 0.15 & $-5.27^{* * *}$ \\
\hline Firm Book Leverage & & 0.25 & 0.23 & $2.08^{* *}$ \\
\hline Firm $M B$ & & 2.46 & 2.92 & $-4.66^{* * *}$ \\
\hline Firm Stock Performance & & 0.27 & 0.40 & $-3.22^{* * *}$ \\
\hline Firm $R \& D /$ Sales & & 0.23 & 0.24 & -0.39 \\
\hline Firm Proceeds/MV Equity & & 0.22 & 0.25 & $-2.25^{* *}$ \\
\hline \multirow[t]{2}{*}{ Panel B } & \multicolumn{2}{|c|}{ Debt versus equity } & \multicolumn{2}{|c|}{ Public debt versus equity } \\
\hline & First stage & Second stage & First stage & Second stage \\
\hline \multicolumn{2}{|l|}{ Tangible \& Non-unique } & $\begin{array}{l}-0.65^{* * *} \\
(0.18)\end{array}$ & & $\begin{array}{l}-0.54^{* * *} \\
(0.20)\end{array}$ \\
\hline \multicolumn{2}{|l|}{$R \& D$} & $\begin{array}{l}0.31 \\
(0.25)\end{array}$ & & $\begin{array}{l}1.22^{* *} \\
(0.54)\end{array}$ \\
\hline \multicolumn{2}{|l|}{$\log ($ Investment Life $)$} & $\begin{array}{l}-0.10 \\
(0.14)\end{array}$ & & $\begin{array}{l}-0.04 \\
(0.16)\end{array}$ \\
\hline \multicolumn{2}{|l|}{ Time until Payoffs } & $\begin{array}{l}0.83^{* * * *} \\
(0.17)\end{array}$ & & $\begin{array}{l}0.26^{*} \\
(0.16)\end{array}$ \\
\hline Investment Life & & 0.15 & & -0.34 \\
\hline \multicolumn{2}{|l|}{$\begin{array}{l}\text { Uncertainty } \\
\text { Volatility }\end{array}$} & $(0.18)$ & & $(0.22)$ \\
\hline \multicolumn{2}{|l|}{ Volatility } & $\begin{array}{l}0.70^{* * * *} \\
(0.19)\end{array}$ & & $\begin{array}{l}0.72^{* * *} \\
(0.27)\end{array}$ \\
\hline \multicolumn{2}{|l|}{ Need for Monitoring } & $\begin{array}{l}-0.38^{* *} \\
(0.17)\end{array}$ & & $\begin{array}{l}-0.98^{* *} \\
(0.46)\end{array}$ \\
\hline \multicolumn{5}{|l|}{ Control variables } \\
\hline Firm HOT & $0.27(0.20)$ & $1.48 * *(0.62)$ & $-0.05(0.25)$ & $0.06(0.83)$ \\
\hline Firm Book Leverage & $-0.16(0.12)$ & $-0.73^{* *}(0.34)$ & $-0.01(0.16)$ & $-0.71(0.46)$ \\
\hline Firm $M B$ & $0.03 *(0.02)$ & $0.11 * *(0.05)$ & $0.03(0.02)$ & $0.11(0.07)$ \\
\hline Firm Stock Performance & $0.05 *(0.03)$ & $0.26^{* * *}(0.08)$ & $0.09 * * *(0.03)$ & $0.38^{* * *}(0.14)$ \\
\hline Firm $R \& D /$ Sales & $-0.01(0.02)$ & $-0.14(0.21)$ & $-0.01(0.09)$ & $0.46(0.45)$ \\
\hline Firm Proceeds/MV Equity & $0.15 *(0.09)$ & $0.13(0.22)$ & $0.16(0.12)$ & $1.22^{* * *}(0.46)$ \\
\hline Industry-year norm & $2.83^{* * *}(0.46)$ & & $4.07^{* * *}(0.57)$ & \\
\hline Reputable investment bank & & & $0.14 * *(0.06)$ & \\
\hline Inverse Mill's ratio & & $0.02(0.61)$ & & $-0.80 *(0.47)$ \\
\hline$N$ & 3406 & & 2080 & \\
\hline$N$ debt-financed & 1643 & & 492 & \\
\hline$N$ equity-financed & 1763 & & 1588 & \\
\hline Censored observations & & 680 & & 451 \\
\hline
\end{tabular}

\section{Table 6}

Factor Analysis. This table reports the results of factor analysis based on the investment characteristics. We present unrotated factor loadings on the first three factors using the principal factor method. Factor loadings less than $|0.20|$ are set to blank.

\begin{tabular}{|c|c|c|c|}
\hline & Principal factors & & \\
\hline$\overline{\text { Investment characteristics }}$ & Factor 1 & $\overline{\text { Factor } 2}$ & $\overline{\text { Factor } 3}$ \\
\hline Eigenvalue & 2.58 & 1.01 & 0.15 \\
\hline Percentage explained & 0.69 & 0.27 & 0.04 \\
\hline Tangible \& Non-unique & -0.48 & 0.45 & 0.23 \\
\hline$R \& D$ & 0.75 & & \\
\hline $\log ($ Investment Life $)$ & & 0.69 & \\
\hline Time until Payoffs & 0.73 & 0.25 & \\
\hline Investment Life Uncertainty & 0.80 & & \\
\hline Volatility & 0.52 & 0.32 & -0.23 \\
\hline Need for Monitoring & 0.55 & 0.35 & \\
\hline
\end{tabular}




\section{Table 7}

The first factor and a logit analysis of the debt-equity choice. This table reports a logit analysis of the debt-equity choice. The factor is factor 1 , as identified in Table 6 . The dependent variable is a dummy equal to one for common equity issues and zero for straight debt issues. See Table 1 for a description of the explanatory variables. Industry dummies are based on the Fama-French 12 industry classification. Period dummies are based on five year intervals. Heteroskedasticity-consistent standard errors clustered at the issuer level are reported in parentheses. $* * *, * *$ and *indicate statistical significance at the $1 \%, 5 \%$ and $10 \%$ level, respectively.

\begin{tabular}{lll}
\hline & Debt-equity choice & \\
\cline { 3 - 3 } & $(1)$ & $(2)$ \\
\hline Factors & $1.47^{* * * *}$ & $1.16^{* * *}$ \\
Factor 1 & $(0.15)$ & $(0.23)$ \\
Control variables & & $2.55^{* * *}(1.10)$ \\
Firm HOT & & $-1.92^{* * * *}(0.60)$ \\
Firm Book Leverage & & $0.30^{* * *}(0.09)$ \\
Firm MB & & $0.62^{* * *}(0.17)$ \\
Firm Stock Performance & & $0.02(0.42)$ \\
Firm R\&D/Sales & No & $0.54(0.52)$ \\
Firm Proceeds/MV Equity & No & Yes \\
Industry dummies & 759 & Yes \\
Period dummies & 0.21 & 680 \\
$N$ & & 0.43 \\
Pseudo $R^{2}$ & & \\
\hline
\end{tabular}

the first factor. Just as studies by Kaplan et al. (2012), Custodio et al. (2013) and Adams et al. (2018) use factor analysis to identify "types" of CEOs and boards, our study suggests that a particular investment "type" is the primary determinant of the debt-equity choice. The first factor loads positively on the $R \& D$ characteristic, the Time until Payoffs, Investment Life Uncertainty, Volatility, and the Need for Monitoring and negatively on the Tangible \& Non-unique characteristic. As such, the first factor seems to represent whether an investment has outcomes that can be described as binary; i.e. whether an investment is associated with downside payoffs that don't reflect a substantial collateral value and are instead close to zero, and upside payoffs that are right-skewed and uncertain in timing and duration. Such investments could be characterized as a hit-or-miss.

In Table 7, we use the first factor as the explanatory variable for the debt-equity choice and employ the same set of control variables used in Table 2. Whether or not the controls are included in the analysis, the results are consistent with binary-outcome investments being significantly more likely to be equity-financed and this first factor capturing the principal dimension of the influence of investment characteristics on the form of external financing. The pseudo $R^{2}$ of a logit regression that simultaneously includes the seven characteristics plus industry and time dummies is $48 \%$ (Table 2, column (4)). When the seven individual characteristics are replaced by the single first factor, the hit-or-miss nature of an investment along with the industry and time dummies is able to explain $43 \%$ of the variation in the debt-equity choice (Table 7, column (2)). For specifications without any controls, the percentage of the variation in the debt-equity choice explained by all seven characteristics is $28 \%$. The hit-or-miss factor alone is able to explain $21 \%$ of the variation in the financing choice.

\section{Convertible issues}

In this section we investigate the characteristics of the 42 investments that are financed by a convertible issue. Convertible bond issues are increasingly used as a means of financing and a substantial literature considers the rationales for doing so (Lewis et al., 1998; Dutordoir et al., 2014). When a sequential program is equity-financed, there is no debt overhang. But financing with equity is not necessarily optimal since equity can fail to discipline managerial opportunism. Although there is also no debt overhang if an investment program is financed by a series of short-term debt issues, each rollover involves additional issuance costs. Mayers (1998) argues that financing via a convertible reduces these issuance costs because callability allows the firm to force conversion and proceed with its desired financing plan only when the preceding stage is successful. Convertibles are especially useful when the life of the first stage is uncertain. Since the call can be synchronized with the resolution of the uncertainty surrounding the first stage, Mayers concludes that issuing a convertible can be the optimal way to finance sequential investment programs.

Panel A of Table 8 reports the mean values of the characteristics of the investments financed by issuing a convertible as well as information on the distribution of the estimated lives of these investments and on the issuing firms' control variables. Panel A further reports whether these means are different from the means of the sample of debt issues and equity issues reported in Panel B of Table 1. Panel B of Table 8 reports the results of a multinomial logit analysis of the financing choice taking the issuance of a convertible as the 


\section{Table 8}

Convertible issue determinants. Panel A reports the descriptive statistics for investments financed by convertible issues and a comparison with debt and equity issues. Panel B reports a multinomial logit analysis. The dependent variable has a separate value for convertible issues, common equity issues, and straight debt issues. We use a convertible issue as the pivot outcome in our estimation. See Table 1 for a description of the explanatory variables. Industry dummies are based on the Fama-French 12 industry classification. Period dummies are based on five-year intervals. Heteroskedasticity-consistent standard errors clustered at the issuer level are reported in parentheses. ***, ** and *indicate statistical significance at the $1 \%, 5 \%$ and $10 \%$ level, respectively.

\begin{tabular}{|c|c|c|c|c|c|c|}
\hline Panel A & $\mathrm{N}$ & Mean & Median & $\begin{array}{l}\text { Standard } \\
\text { deviation }\end{array}$ & $\begin{array}{l}\text { Difference of means statistic for } \\
\text { debt issues }\end{array}$ & $\begin{array}{l}\text { Difference of means statistic for } \\
\text { equity issues }\end{array}$ \\
\hline Tangible & 42 & 0.60 & & & $-5.63^{* * *}$ & $2.13^{* *}$ \\
\hline Unique & 42 & 0.83 & & & $4.67^{* * *}$ & -0.36 \\
\hline Tangible \& Non-unique & 42 & 0.17 & & & $-4.58^{* * *}$ & 0.40 \\
\hline$R \& D$ & 42 & 0.17 & & & $2.62^{* * *}$ & $-2.96^{* * *}$ \\
\hline Investment Life & 42 & 11.38 & 10.00 & 5.49 & $-2.32^{* *}$ & 1.59 \\
\hline Time until Payoffs & 42 & 1.12 & & & $5.62^{* * *}$ & $-2.24^{* *}$ \\
\hline Investment Life Uncertainty & 42 & 0.48 & & & $5.45^{* * *}$ & -0.73 \\
\hline Volatility & 42 & 0.98 & & & $4.34^{* * * *}$ & 1.29 \\
\hline Need for Monitoring & 42 & 0.90 & & & 1.58 & -0.98 \\
\hline Firm HOT & 38 & 0.13 & 0.08 & 0.22 & $2.39 * *$ & -0.78 \\
\hline $\begin{array}{l}\text { Deviation from industry leverage when } \\
\text { issuing debt vs equity }\end{array}$ & 38 & 0.15 & 0.11 & 0.21 & $2.29 * *$ & -1.38 \\
\hline Firm Book Leverage & 38 & 0.25 & 0.20 & 0.25 & -1.40 & 1.53 \\
\hline Firm $M B$ & 38 & 3.50 & 1.93 & 3.16 & $3.11^{* * * *}$ & -0.12 \\
\hline Firm Stock Performance & 38 & 0.48 & 0.14 & 1.12 & $1.71 *$ & -0.40 \\
\hline Firm $R \& D /$ Sales & 38 & 0.28 & 0.04 & 0.42 & $1.99 *$ & -0.18 \\
\hline Firm Proceeds/MV Equity & 38 & 0.20 & 0.12 & 0.33 & -0.13 & -1.31 \\
\hline Panel B & \multirow{2}{*}{\multicolumn{5}{|c|}{ Straight debt versus a convertible issue }} & Equity versus a convertible issue \\
\hline \multicolumn{2}{|l|}{ Characteristics } & & & & & \\
\hline \multirow[t]{2}{*}{ Tangible \& Non-unique } & \multirow{2}{*}{\multicolumn{3}{|c|}{$\begin{array}{l}1.54 * * \\
(0.64)\end{array}$}} & & & 0.31 \\
\hline & & & & & & $(0.59)$ \\
\hline \multirow[t]{2}{*}{$R \& D$} & \multicolumn{3}{|c|}{1.18} & & & 1.17 \\
\hline & \multicolumn{3}{|c|}{$(0.89)$} & & & $(0.72)$ \\
\hline \multirow{2}{*}{$\log ($ Investment Life $)$} & \multicolumn{3}{|c|}{$\begin{array}{l}0.26 \\
(0.48)\end{array}$} & & & -0.52 \\
\hline & \multirow{2}{*}{\multicolumn{3}{|c|}{$\begin{array}{l}(0.48) \\
-0.82^{*}\end{array}$}} & & & $(0.39)$ \\
\hline \multirow[t]{2}{*}{ Time until Payoffs } & & & & & & 0.58 \\
\hline & \multicolumn{3}{|c|}{$\begin{array}{l}-0.82^{\%} \\
(0.47)\end{array}$} & & & $(0.41)$ \\
\hline \multirow[t]{2}{*}{ Investment Life Uncertainty } & \multicolumn{3}{|c|}{-0.84} & & & $-1.28^{* * *}$ \\
\hline & \multicolumn{3}{|c|}{$(0.62)$} & & & $(0.48)$ \\
\hline \multirow[t]{2}{*}{ Volatility } & \multicolumn{3}{|c|}{$-3.04^{* * *}$} & & & $-1.70^{*}$ \\
\hline & & & & & & $(1.01)$ \\
\hline \multirow[t]{2}{*}{ Need for Monitoring } & \multicolumn{3}{|c|}{$\begin{array}{l}(1.02) \\
0.82\end{array}$} & & & 0.44 \\
\hline & \multicolumn{3}{|c|}{$(0.63)$} & & & $(0.55)$ \\
\hline \multicolumn{7}{|l|}{ Control variables } \\
\hline Firm HOT & \multicolumn{4}{|c|}{$-2.91 *(1.68)$} & & $-0.45(1.33)$ \\
\hline Firm Book Leverage & \multicolumn{4}{|c|}{$0.17(1.04)$} & & $-1.31(0.92)$ \\
\hline Firm $M B$ & \multicolumn{4}{|c|}{$-0.26^{* *}(0.11)$} & & $0.02(0.07)$ \\
\hline Firm Stock Performance & & & $39(0.25)$ & & & $0.19(0.20)$ \\
\hline Firm $R \& D /$ Sales & & & $3(0.78)$ & & & $-0.86(0.70)$ \\
\hline Firm Proceeds/MV Equity & & & $(1.01)$ & & & $0.83(0.93)$ \\
\hline Industry dummies & & & & & Yes & \\
\hline Period dummies & & & & & Yes & \\
\hline$N$ & & & & & 718 & \\
\hline Pseudo $R^{2}$ & & & & & 0.40 & \\
\hline
\end{tabular}


pivot outcome. We use a multinomial logit analysis as a Hausman test does not reject the independence of irrelevant alternatives assumption. Our control variables include dummy variables for the time period, which might be particularly relevant for convertible securities due to the increase over the sample period in purchases of new issues of convertible bonds by convertible arbitrage funds (Brown et al., 2012). Column (1) of Panel B reports the likelihood that an investment is financed by straight debt rather than issuing a convertible and Column (2) reports the likelihood of financing with equity rather than a convertible.

The relative likelihood of financing a new investment by issuing straight debt rather than a convertible is higher when the investment's characteristics are such that it can be classified as Tangible and Non-unique. The likelihood of a convertible issue rather than a straight debt issue is increased when investment payoffs have high Volatility and a lengthy Time until Payoffs. The relative likelihood of financing new investment by issuing a convertible rather than equity increases when the investment's characteristics are such that the Investment Life Uncertainty and payoff Volatility characteristics are high. In summary, our results on convertible financing and investment characteristics are in line with Mayers (1998): Highly volatile investment payoffs increase the likelihood of financing via a convertible rather than either debt or equity, and a highly uncertain investment life increases the likelihood of financing via a convertible rather than by issuing equity.

\section{Conclusion}

We analyze a hand-collected data set of the characteristics of investments by U.S. corporations between 1995 and 2017 that are financed externally through an equity issue, convertible bond issue, straight bond issue, or by bank debt. Building on a large capital structure literature, we find that investments with more distant and more volatile payoffs are more likely to be financed with equity. In contrast, investments in tangible non-unique assets or in assets that require a high level of monitoring are more likely to be financed with debt. Our results on convertible financing and investment characteristics are in line with the rationale of Mayers (1998) that convertibles are useful for sequential financing purposes.

The inclusion of investment characteristics substantially increases the explanatory power of a debt-equity choice model that already controls for the firm's existing assets and capital structure. The increase is significant at the $1 \%$ level and shows the important role investment characteristics play in determining the financing of an investment. A result that stands out is the empirical identification of the time until an investment produces positive payoffs as a key determinant of the financing choice: The more distant are payoffs from an externally-financed investment, the more likely it is that the investment is equity financed. Our study further highlights the importance of asset redeployability as a determinant of leverage (Campello and Giambona, 2013; Nyatee, 2017) by interacting tangibility and uniqueness and showing that specific investments that are both tangible and non-unique are significantly more likely to be debt-financed than tangible investments that are unique.

The strong correlations between the seven investment characteristics highlight the importance of our simultaneous examination of the relation between investment characteristics and the financing choice. We use factor analysis to identify a single combination of the seven characteristics that captures the bulk of their explanatory power. This factor is a measure of the extent to which an investment has outcomes that can be characterized as a hit-or-miss: downside payoffs that don't reflect substantial collateral value and rightskewed upside payoffs of uncertain timing and duration. The pseudo $R^{2}$ of a logit regression that includes all seven characteristics is $48 \%$. When the seven individual characteristics are replaced by the single first factor, we are able to explain $43 \%$ of the variation in the debt-equity choice. The hit-or-miss factor loads positively on R\&D, the time until positive payoffs, investment life uncertainty, payoff volatility, and the need for monitoring, and negatively on the tangible, non-unique nature of an investment. Investments that are strongly associated with the hit-or-miss factor are more likely to be equity-financed.

The manual classification of the characteristics in this paper suggests a need for caution in interpretation of our results. Measurement error is though not such that it has precluded finding significant results. Although our analysis cannot completely rule out an omitted variables bias, we note that adding alternative variants of additional control variables to our analysis leaves the sign and significance of the estimated coefficients on the investment characteristics unchanged. We also control for a potential selection bias that might arise if the type of new security issued to finance an investment is in part a determinant of whether the contemporaneous prospectus, SEC filings, and corporate news releases contain sufficient information to determine the characteristics of the investment. Because a sample of externally-financed investments necessarily conditions on the firm being either unwilling or unable to finance via retained earnings, the results in this study are conditional on firms deciding to raise financing externally. Future work might potentially provide more insights into the characteristics of internally-financed investments, for example through questionnaires (Graham and Harvey, 2001; Brounen et al., 2006). Future work might also examine non-U.S. countries such as Japan, where it is relatively common to report detailed information on investments (Dutordoir et al., 2016).

\section{Appendix A. Twenty examples of investments and their characteristics}




\begin{tabular}{|c|c|c|c|c|c|c|c|c|c|c|}
\hline Issuer Name & $\begin{array}{l}\text { Security issue } \\
\text { date }\end{array}$ & Brief description of investment & Tangible & Unique & $R \& D$ & $\begin{array}{l}\text { Inv. } \\
\text { Life }\end{array}$ & $\begin{array}{l}\text { Time until } \\
\text { Payoffs }\end{array}$ & $\begin{array}{l}\text { Inv. Life } \\
\text { Uncertainty }\end{array}$ & Volatility & $\begin{array}{l}\text { Need for } \\
\text { Monitoring }\end{array}$ \\
\hline Tropical Sportswear & 1996-05-07 & Construction of new cutting facility & 1 & 0 & 0 & 25 & 1 & 0 & 0 & 1 \\
\hline Targeted Genetics & $1998-11-23$ & $\begin{array}{l}\text { Design and construct manufacturing facility for clinical trials and } \\
\text { production }\end{array}$ & 1 & 1 & 1 & 15 & 1 & 1 & 1 & 1 \\
\hline Cytogen & $1999-12-30$ & Purchase computers and equipment & 1 & 1 & 0 & 4 & 0 & 0 & 0 & 0 \\
\hline MBC Holding & 2001-03-29 & Equipment upgrades & 1 & 0 & 0 & 8 & 1 & 0 & 0 & 1 \\
\hline Applied Molecular Evolution & 2002-03-31 & Purchase land and develop headquarters & 1 & 0 & 0 & 25 & 1 & 0 & 1 & 1 \\
\hline Dusa Pharmaceuticals & $2002-05-13$ & $\begin{array}{l}\text { Construct drug manufacturing facility for a drug previously acquired } \\
\text { from another company }\end{array}$ & 1 & 0 & 0 & 15 & 1 & 0 & 1 & 2 \\
\hline Diedrich Coffee & 2002-09-03 & Purchase packaging equipment & 1 & 1 & 0 & 10 & 0 & 0 & 0 & 0 \\
\hline Goldfield & 2004-01-30 & Purchases of electrical construction equipment & 1 & 0 & 0 & 4 & 0 & 0 & 0 & 0 \\
\hline Norwegian Cruise Line & 2004-04-14 & Construction of cruise ship & 1 & 0 & 0 & 30 & 1 & 0 & 1 & 1 \\
\hline Venetian Casino Resort & 2004-09-30 & Mall construction costs & 1 & 0 & 0 & 30 & 1 & 0 & 1 & 1 \\
\hline Alaska Airlines & 2005-03-25 & Purchasing aircraft & 1 & 0 & 0 & $22^{1 / 2}$ & 1 & 0 & 1 & 1 \\
\hline Penford & 2006-10-05 & Construction of ethanol production facility & 1 & 1 & 0 & 20 & 1 & 0 & 1 & 2 \\
\hline Globalstar & 2009-06-05 & Satellite construction & 1 & 1 & 0 & 8 & 1 & 1 & 1 & 2 \\
\hline $\mathrm{N}$-Viro Internat. & 2010-07-07 & Develop flexible test facility & 1 & 1 & 1 & 12 & 1 & 1 & 1 & 2 \\
\hline Kythera Biopharmaceut. & 2015-03-10 & Development and commercialize product candidate & 0 & 1 & 1 & $7 \frac{1}{2}$ & 1 & 1 & 1 & 1 \\
\hline Akebia Therapeutics & 2015-04-16 & Continuation of clinical development of products & 0 & 1 & 1 & $71 / 2$ & 2 & 1 & 1 & 1 \\
\hline Orchids Paper Products & 2015-04-23 & Construction of manufacturing facility & 1 & 1 & 0 & 20 & 1 & 0 & 0 & 1 \\
\hline TherapeuticsMD & 2015-07-09 & Commercialize products currently in clinical trials & 0 & 1 & 1 & $7 \frac{1}{2}$ & 1 & 1 & 1 & 1 \\
\hline Parsley Energy & 2015-12-09 & Purchase gas fields & 1 & 0 & 0 & 12 & 2 & 1 & 1 & 1 \\
\hline ImmuCell & 2016-01-29 & Facility construction & 1 & 0 & 0 & 15 & 1 & 0 & 1 & 1 \\
\hline
\end{tabular}




\section{References}

Acharya, Viral V., Sundaram, Rangarajan K., John, Kose, 2011. Cross-country variations in capital structures: the role of bankruptcy codes. J. Financ. Intermed. 20, 25-54.

Adam, Tim, Goyal, Vidhan K., 2008. The investment opportunity set and its proxy variables. J. Financ. Res. 31 (1), $41-63$.

Adams, Renee, Akyol, Ali, Verwijmeren, Patrick, 2018. Director skill sets. J. Financ. Econ. 130 (3), 641-662.

Anderson, Ronald, Duru, Augustine, Reeb, David, 2012. Investment policy in family controlled firms. J. Bank. Financ. 36, 1744-1758.

Baker, Malcolm, 2009. Capital market driven corporate finance. Ann. Rev. Fin. Econ. 1, 1-41.

Baker, Malcolm, Wurgler, Jeffrey, 2002. Market timing and capital structure. J. Financ. 57 (1), 1-32.

Barclay, Michael J., Smith, Clifford W., 1995. The maturity structure of corporate debt. J. Financ. 50 (2), $609-631$.

Barclay, Michael J., Smith Jr., Clifford W., Morellec, Erwan, 2006. On the debt capacity of growth options. J. Bus. 79 (1), 37-60.

Barnea, Amir, Talmor, Eli, Haugen, Robert A., 1987. Debt and taxes: a multiperiod investigation. J. Bank. Financ. 11 (1), $79-97$.

Benmelech, Efraim, 2009. Asset salability and debt maturity: evidence from nineteenth-century American railroads. Rev. Financ. Stud. 22 (4), 1545-1584.

Berens, James L., Cuny, Charles J., 1995. The capital structure puzzle revisited. Rev. Financ. Stud. 8 (4), 1185-1208.

Brounen, Dirk, de Jong, Abe, Koedijk, Kees, 2006. Capital structure policies in Europe: survey evidence. J. Bank. Financ. 30 (5), 1409-1442.

Brown, Stephen J., Grundy, Bruce D., Lewis, Craig M., Verwijmeren, Patrick, 2012. Convertibles and hedge funds as distributors of equity exposure. Rev. Financ. Stud. 25, 3077-3112.

Burkart, Mike, Gromb, Denis, Panunzi, Fausto, 1997. Large shareholders, monitoring, and the value of the firm. Q. J. Econ. 112 (3), 693-728.

Campello, Murillo, Giambona, Erasmo, 2013. Real assets and capital structure. J. Financ. Quant. Anal. 48 (5), $1333-1370$.

Cortazar, Gonzalo, Schwartz, Eduardo S., Casassus, Jaime, 2001. Optimal exploration investments under price and geological uncertainty: a real options model. R\&D Manag. J. 31 (2), 181-189.

Cumming, Douglas, 2005. Capital structure in venture finance. J. Corp. Finan. 11, 550-585.

Custodio, Claudia, Ferreira, Miguel A., Matos, Pedro, 2013. Generalists versus specialists: lifetime work experience and chief executive officer pay. J. Financ. Econ. 108 (2), 471-492.

Denis, David J., Mihov, Vassil T., 2003. The choice among bank debt, non-bank private debt, and public debt: evidence from new corporate borrowings. J. Financ. Econ. 70 (1), 3-28.

Dudley, Evan, 2012. Capital structure and large investment projects. J. Corp. Finan. 18 (5), 1168-1192.

Dutordoir, Marie, Lewis, Craig M., Seward, James, Veld, Chris, 2014. What we do and do not know about convertible bond financing. J. Corp. Finan. 24, 3-20.

Dutordoir, Marie, Li, Lui, Liu, Frank Hong, Verwijmeren, Patrick, 2016. Convertible bond announcement effects: why is Japan different? J. Corp. Finan. 37, 76-92.

Dutordoir, Marie, Neto, Joao Q.F., Strong, Norman, Sun, Ping, 2017. Do Stated Use of Proceeds Affect Stock Price Reactions to Security Offerings? (Working paper). Edmans, Alex, 2014. Blockholders and corporate governance. Ann. Rev. Fin. Econ. 6, 23-50.

Elsas, Ralf, Flannery, Mark J., Garfinkel, Jon A., 2014. Financing major investments: information about capital structure decisions. Rev. Fin. 18 (4), $1341-1386$.

Fang, Lily H., 2005. Investment bank reputation and the price and quality of underwriting services. J. Financ. 60 (6), $2729-2761$.

de Fiore, Fiorella, Uhlig, Harald, 2011. Bank finance versus bond finance. J. Money, Credit, Bank. 43 (7), 1395-1418.

Flannery, Mark J., Rangan, Kasturi P., 2006. Partial adjustment toward target capital structures. J. Financ. Econ. 79 (3), $469-506$.

Frank, Murray Z., Goyal, Vidhan, 2009. Capital structure decisions: which factors are reliably important? Financ. Manag. 38 (1), 1-37.

Frantz, Pascal, Instefjord, Norvald, 2019. Debt overhang and non-distressed debt restructuring. J. Financ. Intermed. 37, 75-88.

Fraumeni, Barbera M., 1997. The measurement of depreciation in the U.S. National Income and Product Accounts. In: Survey of Current Business July, pp. 7-23. Graham, John R., 1996. Debt and the marginal tax rate. J. Financ. Econ. 41 (1), 41-73.

Graham, John R., Harvey, Campbell R., 2001. The theory and practice of corporate finance: evidence from the field. J. Financ. Econ. 60, 187-243.

Grundy, Bruce D., 1977. Capital Structure and Firm Value in Perfect and Imperfect Markets. University of Queensland Honours Thesis.

Guedes, Jose, Opler, Tim, 1996. The determinants of the maturity of corporate debt issues. J. Financ. 51 (5), 1809-1833.

Hart, Oliver, Moore, John, 1994. A theory of debt based on the inalienability of human capital. Q. J. Econ. 109 (4), 841-879.

Haugen, Robert A., Senbet, Lemma W., 1978. The insignificance of bankruptcy costs to the theory of optimal capital structure. J. Financ. 33 (2), 383-393.

Heckman, James J., 1979. Sample selection bias as a specification error. Econometrica 47 (1), 153-161.

Hellman, Thomas, Stiglitz, Joseph, 2000. Credit and equity rationing in markets with adverse selection. Eur. Econ. Rev. 44 (2), $281-304$.

Hovakimian, Armen, Opler, Tim, Titman, Sheridan, 2001. The debt-equity choice. J. Financ. Quant. Anal. 36 (1), 1-24.

Hsu, Jason C., Schwartz, Eduardo S., 2008. A model of R\&D valuation and the design of research incentives. Insurance Math. Econ. 43 (3), $350-367$.

de Jong, Abe, Verbeek, Marno, Verwijmeren, Patrick, 2010. The impact of financing surpluses and large financing deficits on tests of the pecking order theory. Financ.

Manag. 39 (2), 733-756.

Kaplan, Stephen N., Klebanov, Mark M., Sorensen, Morten, 2012. Which CEO characteristics and abilities matter? J. Financ. 67 (3), $973-1007$.

Kim, Hyunseob, Kung, Howard, 2017. The asset redeployability channel: how uncertainty affects corporate investment. Rev. Financ. Stud. 30 (1), 245-280.

Lattin, James M., Carroll, Douglas, Green, Paul E., 2003. Analyzing Multivariate Data. Thomson Brooks/Cole.

Lemmon, Michael L., Roberts, Michael R., Zender, Jaime F., 2008. Back to the beginning: persistence and the cross-section of corporate capital structure. J. Financ. 63 (4), 1575-1608.

Lewis, Craig M., Rogalski, Richard J., Seward, James K., 1998. Agency problems, information asymmetries, and convertible debt security design. J. Financ. Intermed. 7, 32-59.

Li, Jay Y., Mauer, David C., 2016. Financing uncertain growth. J. Corp. Finan. 41, 241-261.

MacKie-Mason, Jeffrey K., 1990. Do taxes affect corporate financing decisions? J. Financ. 45, 1471-1493.

Mayers, David, 1998. Why firms issue convertible bonds: the matching of financial and real investment options. J. Financ. Econ. 47 (1), 83-102.

Myers, Stewart C., 1977. Determinants of corporate borrowing. J. Financ. Econ. 5 (2), 147-175.

Myers, Stewart C., Majluf, Nicholas S., 1984. Corporate financing and investment decisions when firms have information that investors do not have. J. Financ. Econ. 13 (2), 187-221.

Nyatee, Anisha, 2017. Asset Redeployability and Capital Structure Choice: The Role of Competition. Available at SSRN: https://ssrn.com/abstract=3033151.

Rajan, Raghuram, 1992. Insiders and outsiders: the choice between informed and arm's-length debt. J. Financ. 47 (4), 1367-1400.

Rajan, Raghuram, Winton, Andrew, 1995. Covenants and collateral as incentives to monitor. J. Financ. 50 (4), $1113-1146$.

Rampini, Adriano A., 2019. Financing durable assets. Am. Econ. Rev. 109 (2), 664-701.

Shleifer, Andrei, Vishny, Robert W., 1992. Liquidation values and debt capacity: a market equilibrium approach. J. Financ. 47 (4), $143-166$.

Stohs, Mark Hoven, Mauer, David C., 1996. The determinants of corporate debt maturity structure. J. Bus. 69 (3), $279-312$.

Strebulaev, Ilya A., 2007. Do tests of capital structure theory mean what they say? J. Financ. 62 (4), 1747-1787.

Strebulaev, Ilya A., Yang, Baozhong, 2013. The mystery of zero-leverage firms. J. Financ. Econ. 109 (1), 1-23.

Titman, Sheridan, 1984. The effect of capital structure on a firm's liquidation decision. J. Financ. Econ. 13 (1), $137-151$.

Titman, Sheridan, Wessels, Roberto, 1988. The determinants of capital structure choice. J. Financ. 43 (1), 1-19.

Tsyplakov, Sergey, 2008. Investment frictions and leverage dynamics. J. Financ. Econ. 89 (3), 423-443.

Walker, Mark D., Yost, Keven, 2008. Seasoned equity offerings: what firms say, do, and how the market reacts. J. Corp. Finan. 14 , $376-386$. Warusawitharana, Missaka, Whited, Toni, 2016. Equity market misvaluation, financing, and investment. Rev. Financ. Stud. 29 (3), $603-654$. White, Michelle J., 1989. The corporate bankruptcy decision. J. Econ. Perspect. 3 (2), 129-151. 